\title{
Re-Assessment of Forest Carbon Balance in Southeast Asia: Policy Implications for REDD+
}

\author{
Vathana Khun ${ }^{1,2}$, Nophea Sasaki ${ }^{1,3}$ \\ ${ }^{1}$ Graduate School of Applied Informatics, University of Hyogo, Kobe, Japan \\ ${ }^{2}$ National REDD+ Taskforce Secretariat, Forestry Administration, Phnom Penh, Cambodia \\ ${ }^{3}$ School of Earth and Environmental Sciences, University of Adelaide, Adelaide, Australia \\ Email: vathana.khun@gmail.com, nophea.sasaki@adelaide.edu.au
}

Received 8 September 2014; revised 5 October 2014; accepted 2 November 2014

Copyright (C) 2014 by authors and Scientific Research Publishing Inc.

This work is licensed under the Creative Commons Attribution International License (CC BY). http://creativecommons.org/licenses/by/4.0/

(c) (i) Open Access

\section{Abstract}

Southeast Asia is rich in tropical forests and biodiversity but rapid deforestation and forest degradation have accelerated climate change and threatened sustainable development in the region. Carbon emission reductions through reducing deforestation and forest degradation, forest conservation, sustainable management of forests, and enhancement of forest carbon stocks (REDD+) have been a focal topic of the climate change mitigation since the Bali in 2007. However, only a handful of studies exist so far on this important issue that are suitable to inform the debate with estimates of carbon stocks and emission reductions or removals as a result of REDD+. Our study attempts to analyze the potential emission reductions and removals for a 35 -year period under the REDD+ scheme. We start by developing land use change and forest harvesting models that are used to estimate carbon stock changes in natural forests and forest plantations in Southeast Asia. Carbon emissions from deforestation and forest degradation of natural forests were 1865.1, 1611.4, and 1300.4 $\mathrm{TgCO}_{2}$ year-1, respectively. With a hypothetical carbon project of 35 years beginning from 2015, carbon emission reductions were estimated at $817.6 \mathrm{TgCO}_{2}$ year-1, of which about $10 \%$ was from reducing forest degradation. Carbon removals due to increase of forest plantations were $76.3 \mathrm{TgCO}_{2}$ year-1 $^{-1}$ but the removals could be much higher if there is a new definition on the eligibility of forest plantations. Summing up together, about $893.9 \mathrm{TgCO}_{2}$ of carbon credits could be achieved from implementing carbon project in Southeast Asia or about US \$6.6 billion annually between 2015 and 2050 if carbon price in 2012 is used. In addition to reducing emissions, there are other benefits from carbon project implementation. This study suggests that REDD+ has great potential for reducing carbon emissions and enhancing carbon stocks in the forests. Without financial incentives, carbon project would not happen and therefore climate change will continue to threaten future development. 


\section{Keywords}

\section{Carbon Emissions, Carbon Finance, Deforestation, Forest Degradation, Tropical Forests}

\section{Introduction}

Annual carbon emissions due to deforestation in the tropics were estimated ranging from $1.1 \mathrm{PgC}$ [1] to $1.5 \mathrm{PgC}$ [2], and up to $2.2 \pm 0.6 \mathrm{PgC}$ [3] during $1990 \mathrm{~s}\left(1 \mathrm{PgC}=10^{15} \mathrm{gC}\right)$. These emissions account for about $13.7 \%$ to $27.5 \%$ of the 8.0 PgC of global emissions. Furthermore, including selective logging, drought-induced mortality and fire in those calculations may lead to double those emissions [4] [5], accompanied by even higher losses of biodiversity. It is thus not surprising that the issue of reducing deforestation in the tropics has again become a central theme of the United Nations Framework Convention on Climate Change (UNFCCC). This is especially true after the Thirteen Conference of the Parties (COP13) of UNFCCC adopted the Bali Action Plan in 2007 (Decision 2) [6] recognizing the increasingly important role of tropical forests in greenhouse gas emissions reductions through the reduced emissions from deforestation and forest degradation, conservation of forests, sustainable management of forests, enhancement of forest carbon stocks (REDD+) in developing countries. The Action Plan encourages the parties to start implementing the REDD on a voluntary basis while negotiations for official inclusion of the REDD as a mitigation option for the post-Kyoto climate agreement [6] are continuing. Discussions on including reduced deforestation in the post-Kyoto agreement have been made [7]-[10], while discussions on reduced forest degradation are usually ignored due to difficulties in accurately detecting carbon emissions from degradation [11]. However, although the REDD has great potentials because of its remarkably low cost [8], the magnitude of carbon emissions from deforestation and forest degradation in tropical forests has been highly controversial [12]-[15] with errors likely to be as high as $\pm 30 \%$ to $\pm 60 \%$ [12] [16]. Most recent studies by Pan et al. [17] estimated carbon emissions from tropical deforestation (natural forests) at 2.9 PgC but were compensated by the increase of carbon sinks from forest plantations at 1.6 PgC annually between 1990 and 2007. Previous studies suggest the need for further research on forest carbon assessment so that uncertainties can be reduced. Reducing scale of carbon assessment from global to regional or even national scale is likely to reduce such uncertainties.

Using available data between 1980 and 2000 [18], Kim Phat et al. [19] developed land use change and forest carbon models to assess forest carbon stock changes affected by forest management in Southeast Asia. Their study suggests that deforestation in Southeast Asia resulted in carbon emissions of $465 \mathrm{TgC}(1 \mathrm{TgC}=$ million tonnes carbon) per year or about $29 \%$ of the global net carbon release from deforestation worldwide during 1990 and 2000. In addition to reducing deforestation, switching from conventional forest management (i.e. using conventional logging) to a more responsible forest management (i.e. using reduced impact logging) could further reduce carbon emissions depending on chosen management scenarios and financial incentives. Their findings indicate that reducing deforestation and improving logging practices can significantly contribute to reducing carbon emissions from deforestation and forest degradation while increasing timber and carbon-based revenues in Southeast Asia. As more data become increasingly available and international efforts made substantial progresses towards including reducing deforestation and forest degradation in the climate change mitigation option, re-assessment of forest carbon stock changes and emission reductions or removals or both becomes necessary for Southeast Asian countries.

The aim of this paper is, therefore, to provide a re-assessment estimate of the combined carbon emissions due to deforestation and forest degradation, the contribution of forest plantations to the forest carbon stocks in Southeast Asia. A further objective of this report is to develop a number of suitable scenarios and to estimate the results and impacts of REDD+ for a 35-year hypothetical project, which here is assumed to comprise the years 2015 to 2050.

This study will revisit the recently available data [20] with a focus on natural forests and forest plantations in Southeast Asia. The purpose is to project past changes of carbon stocks and emissions onto the period 1990 to 2050, during which a hypothetic REDD+ project is implemented from 2015 until 2050. It uses a generalized but comprehensive regional approach with representative estimates of the main factors controlling the carbon stocks under land use change and different forms of forest management, including forest protection, illegal logging, 
and reduced deforestation.

\section{Study Materials and Methods}

\subsection{Forest Land Use Changes}

Data on the total area of natural forests and forest plantations in the tropics in 1990, 2000, 2005, and 2010 were obtained by summing up the estimated area of all forests in Southeast Asia (Table 1) as reported in FAO [20]. FAO [20] categorized six forest types according to function, namely production, protection, conservation, social services, multiple purpose, and unspecific purpose. Based on those definitions (see Note under Table 2), we can

Table 1. Area of natural forests and forest plantations in Southeast Asia (unit: million ha).

\begin{tabular}{|c|c|c|c|c|c|c|c|c|c|c|c|c|}
\hline \multirow{2}{*}{ Country } & \multicolumn{4}{|c|}{ Natural Forest } & \multicolumn{4}{|c|}{ Forest Plantations } & \multicolumn{4}{|c|}{ Total Forest Area } \\
\hline & 1990 & 2000 & 2005 & 2010 & 1990 & 2000 & 2005 & 2010 & 1990 & 2000 & 2005 & 2010 \\
\hline Brunei Darussalam & 0.41 & 0.40 & 0.39 & 0.38 & 0.00 & 0.00 & 0.00 & 0.00 & 0.41 & 0.40 & 0.39 & 0.38 \\
\hline Cambodia & 12.88 & 11.47 & 10.66 & 10.03 & 0.07 & 0.08 & 0.07 & 0.07 & 12.94 & 11.55 & 10.73 & 10.09 \\
\hline Indonesia & 118.55 & 95.74 & 94.16 & 90.88 & 0.00 & 3.67 & 3.70 & 3.55 & 118.55 & 99.41 & 97.86 & 94.43 \\
\hline Laos & 17.31 & 16.43 & 15.92 & 15.53 & 0.00 & 0.10 & 0.22 & 0.22 & 17.31 & 16.53 & 16.14 & 15.75 \\
\hline Malaysia & 20.42 & 19.93 & 19.32 & 18.65 & 1.96 & 1.66 & 1.57 & 1.81 & 22.38 & 21.59 & 20.89 & 20.46 \\
\hline Myanmar & 38.82 & 34.17 & 32.47 & 30.79 & 0.39 & 0.70 & 0.85 & 0.99 & 39.22 & 34.87 & 33.32 & 31.77 \\
\hline Philippines & 6.27 & 6.79 & 7.05 & 7.31 & 0.30 & 0.33 & 0.34 & 0.35 & 6.57 & 7.12 & 7.39 & 7.67 \\
\hline Singapore & 0.00 & 0.00 & 0.00 & 0.00 & 0.00 & 0.00 & 0.00 & 0.00 & 0.00 & 0.00 & 0.00 & 0.00 \\
\hline Thailand & 16.88 & 15.89 & 15.45 & 14.99 & 2.67 & 3.11 & 3.44 & 3.99 & 19.55 & 19.00 & 18.90 & 18.97 \\
\hline Timor-Leste & 0.94 & 0.81 & 0.76 & 0.70 & 0.03 & 0.04 & 0.04 & 0.04 & 0.97 & 0.85 & 0.80 & 0.74 \\
\hline Viet Nam & 8.40 & 9.68 & 10.28 & 10.29 & 0.97 & 2.05 & 2.79 & 3.51 & 9.36 & 11.73 & 13.08 & 13.80 \\
\hline Southeast Asia & 240.87 & 211.31 & 206.45 & 199.53 & 6.39 & 11.74 & 13.04 & 14.53 & 247.26 & 223.05 & 219.50 & 214.06 \\
\hline
\end{tabular}

Source: [20].

Table 2. Primary designated functions of forest in 2010 and its use in this study.

\begin{tabular}{|c|c|c|c|c|c|c|c|c|}
\hline \multirow[b]{2}{*}{ Country } & \multicolumn{6}{|c|}{ Primary designated function ${ }^{*}$ ( $\%$ of total forest area) } & \multicolumn{2}{|c|}{ Use for this study (\%) } \\
\hline & A & B & $\mathrm{C}$ & $\mathrm{D}$ & $\mathrm{E}$ & $\mathrm{F}$ & $\begin{array}{c}\text { Production } \\
(\mathrm{PdF}=\mathrm{A}+\mathrm{E}+\mathrm{F})\end{array}$ & $\begin{array}{c}\text { Protection } \\
(\operatorname{PrF}=\mathrm{B}+\mathrm{C}+\mathrm{D})\end{array}$ \\
\hline Brunei Darussalam & 58 & 5 & 21 & 1 & 0 & 15 & 73 & 27 \\
\hline Cambodia & 33 & 5 & 39 & 1 & 4 & 17 & 54 & 46 \\
\hline Indonesia & 53 & 24 & 16 & 0 & 0 & 7 & 60 & 40 \\
\hline Laos & 23 & 58 & 19 & - & 0 & 0 & 23 & 77 \\
\hline Malaysia & 62 & 13 & 10 & 0 & 15 & 0 & 77 & 23 \\
\hline Myanmar & 62 & 4 & 7 & 0 & 27 & 0 & 89 & 11 \\
\hline Philippines & 76 & 8 & 16 & 0 & 0 & 0 & 76 & 24 \\
\hline Singapore & 0 & 0 & 100 & 0 & 0 & 0 & 0 & 100 \\
\hline Thailand & 14 & 7 & 47 & 1 & 0 & 32 & 46 & 54 \\
\hline Timor-Leste & 33 & 42 & 25 & 0 & 0 & 0 & 33 & 67 \\
\hline Viet Nam & 47 & 37 & 16 & 0 & 0 & 0 & 47 & 53 \\
\hline \multicolumn{7}{|c|}{ Southeast Asia (weighted average by forest area) } & 61 & 39 \\
\hline
\end{tabular}

*: Definitions of forest functions according to FAO (2005). 1) Production (A): Forest/other wooded land designated for production and extraction of forest goods, including both wood and non-wood forest products (NWFPs). 2) Protection of soil and water (B): Forest/other wooded land designated for protection of soil and water. 3) Conservation of biodiversity (C): Forest/other wooded land designated for conservation of biological diversity. Includes, but is not limited to, protected areas. 4) Social services (D): Forest/other wooded land designated for the provision of social services. These services may include recreation, tourism, education and/or conservation of cultural/spiritual sites. 5) Multiple purpose (E): Forest/other wooded land designated for any combination goods, protection of soil and water, conservation of biodiversity of socio-cultural services, and where none of these alone being significantly more important than the others. 6) Unknown function (unspecific, F): Forest/other wooded land for which a specific function or where the designated function is unknown. For this study, No. 1, No. 5, and No. 6 above were classified as production forest (PdF), and the rest were classified as protected forest $(\mathrm{PrF})$. 
classify tropical forests into two types, namely production forest (PdF, comprising production, multiple-purpose, and unspecific-purpose forests) and protection forests (PrF: protection, conservation and social services forests). Protection forest is forest that is normally protected from commercial logging and forest clearing, while production forest is forest designated for commercial logging, clearing for forest plantation, agricultural cultivation, and other purposes as and when needed. Both PrF and PdF are natural forests, to which we add a third category, forest plantations (FP). The change in area of forest plantations and natural production forest are estimated according to a method modified from Kim Phat et al. [19]. The equations used are:

$$
\begin{gathered}
\frac{\mathrm{dPdF}(t)}{\mathrm{d} t}=(a+b) \times \operatorname{PdF}(t) \\
\frac{\mathrm{dPrF}(t)}{\mathrm{d} t}=0 \\
\frac{\mathrm{dFP}(t)}{\mathrm{d} t}=a \times \operatorname{PdF}(t)
\end{gathered}
$$

where $\operatorname{PdF}(t), \operatorname{PrF}(t)$ and $\operatorname{FP}(t)$ are areas of production forest, protected forest and forest plantations in million ha at time $t$ (in years), $a+b$ is the change rate of PdF, $a$ is the conversion rate from PdF to FP, and $\mathrm{b}$ the conversion rate from PdF to other land use types, such as agricultural lands, resettlements or urban build-up. Table 1 shows the available data for natural forest and forest plantation in 1990, 2000, 2005, and 2010 by country in Southeast Asia. Proportion of PrF between 2005 and 2009 did not change and therefore it is assumed that its area remains constant throughout the modeling period between 1990 and 2050 (Table 2, Table 3). A least-square fit to calculate $a+b \quad a$ and initial values at time $t=0$ (corresponding to 1990) for PdF, and

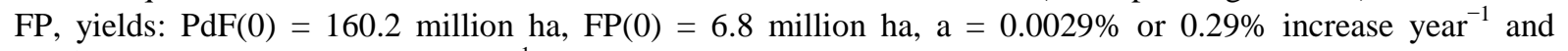
$a+b=-0.0146$ or $1.46 \%$ loss year $^{-1}$ (Table 3 ).

\subsection{Forest Carbon Stocks and Stock Changes}

In the modeling framework developed here, carbon stocks in forests can be affected either by full land-use conversion (activity data described in Equations (1)-(3) or by change in the carbon stock within a particular forest type (emission factor). The former is related to the term "deforestation" in REDD+, the latter causes "degradation" depending on harvesting intensity and related damages. In this study, forest degradation is defined as the loss of carbon stock in a standing forest at any given time compared to the previous year. This may be due to overexploitation (legal or illegal), resulting in carbon loss from unsustainable harvesting. Additional cause is logging damages to the residual forest stands caused by logging operations that exceed natural increments (termed hereafter as the "Mean Annual Increment”, MAI) of a forest in question. Although small-scale logging is carried out in protected forests for local consumption by forest dependent communities who reside in the protected forest, and carbon stocks in PrF is assumed to be constant during the modeling period; this is based on the fact that carbon loss due to small-scale logging is equally compensated by natural regeneration. A separate car-

\begin{tabular}{|c|c|c|c|c|}
\hline Year & Production Forest (PdF) & Protected Forest (PrF) & Forest Plantations (FPl) & Total \\
\hline 1990 & 163.1 & 77.8 & 6.4 & 247.3 \\
\hline 2000 & 133.5 & 77.8 & 11.7 & 223.0 \\
\hline 2005 & 128.7 & 77.8 & 13.0 & 219.5 \\
\hline 2010 & 121.7 & 77.8 & 14.5 & 214.0 \\
\hline Assumptions & $\begin{array}{l}\text { Deforestation but some of the } \\
\text { deforested area is replanted }\end{array}$ & $\begin{array}{l}\text { Remain constant throughout } \\
\text { the modeling period }\end{array}$ & $\begin{array}{l}\text { Increase due to replanting } \\
\text { on deforested land }\end{array}$ & \\
\hline Parameters & $\begin{array}{l}\mathrm{a}+\mathrm{b}=-0.0146(1.46 \% \\
\text { decrease annually) }\end{array}$ & & $\begin{array}{l}a=0.0029 \text { ( } 0.29 \% \\
\text { increase annually) }\end{array}$ & \\
\hline Initials & 160.2 & & 6.8 & \\
\hline
\end{tabular}
bon stock model accounts for the very different dynamics of forest plantations (FP).

Table 3. Production and protected forests and forest plantations used in land use model. 
Although five carbon pools need to be reported by parties to the UNFCCC [21], this study only considers the following pools: aboveground, belowground, litters and deadwood. Role of soil carbon as carbon sink or source is uncertain, either a sink [22] [23] or a source [23]. For lack of data, the present study does not include soil carbon (another carbon pool). Future studies should include soil carbon when data for different land uses after deforestation become available.

Natural forest. Natural forests (PdF and PrF) are usually the state-owned forests, where logging, clearing or protection can take place depending whether it is PdF or PrF. For PdF, individual country grants concession rights to logging companies for harvesting and managing under the terms of agreement and forest management guidelines such as forest concession management, the forestry code of logging practices, or the like. Forest concessionaire (logging company) pays to government the license fees, timber royalties and other fees (see [24] for more) for the rights to manage and harvest the forests. The model for carbon stock changes in natural forests modifies the one by Kim Phat et al. [19]. It assumes that within a concession (i.e. production forest), different parcels of land undergo a cutting cycle of length CC (years), and within this parcel of land, a fraction $f_{H}$ of the mature trees-themselves comprising a fraction $f_{M}$ of all trees-are cut. $f_{H}$ is regulated by forest harvesting law or the forestry code of logging practice. The model allows for illegal logging by defining an illegal logging rate $r$ (see Kim Phat et al. [19]). Illegal logging is defined as the harvesting of wood without government-issued license.

Carbon stock, CS $(t)$ in PdF or PrF can thus be estimated by:

$$
\mathrm{CS}(t)=\mathrm{CS}_{\text {above }}(t)+\mathrm{CS}_{\text {below }}+\mathrm{CS}_{\text {litters }}+\mathrm{CS}_{\text {dead }}+\mathrm{CS}_{\text {soil }}+\mathrm{CS}_{\mathrm{HWP}}
$$

where $\mathrm{CS}_{\text {above }}(t)$ is aboveground carbon, $\mathrm{CS}_{\text {below }}$ is belowground carbon, $\mathrm{CS}_{\text {dead }}$ is carbon in deadwood, $\mathrm{CS}_{\text {litters }}$ is carbon in litters, and CS $_{\text {soil }}$ is carbon in soil. According to IPCC Good Practices [21] (IPCC 2006), including carbon in harvested wood product $\left(\mathrm{CS}_{\mathrm{HWP}}\right)$ is optional. For this study, $\mathrm{CS}_{\text {soil }}$ and $\mathrm{CS}_{\mathrm{HWP}}$ are not accounted for. Except $\mathrm{CS}_{\text {above }}(t)$, logging does not significantly affect $\mathrm{CS}_{\text {below }}, \mathrm{CS}_{\text {below }}$, and $\mathrm{CS}_{\text {below }}$ and therefore for simplicity, carbon in these three pools are assumed to be constant proportional to $\mathrm{CS}_{\text {above }}(t)$ throughout the modeling period. REDD+ project implementation is assumed to be undertaken in 2015 for 35 years until 2050. A 35-year project cycle is a common duration of forestry carbon projects being implemented elsewhere in the tropics. All units are $\mathrm{MgC} \cdot \mathrm{ha}^{-1}\left(1 \mathrm{MgC}=10^{6} \mathrm{gC}\right)$, except otherwise stated. $\mathrm{CS}_{\text {above }}(t)$ can be accounted by

$$
\frac{\mathrm{dCS}_{\text {above }}(t)}{\mathrm{d} t}=\mathrm{MAI}-[\mathrm{LM}(t)+\mathrm{H}(t)] \times \mathrm{BEF}
$$

where $t$ is time (year), MAI is mean annual increment $\left(\mathrm{MgC} \cdot \mathrm{ha}^{-1} \cdot \mathrm{year}^{-1}\right), \operatorname{LM}(t)$ is logging mortality, $\mathrm{H}(t)$ is harvested carbon $\left(\mathrm{MgC} \cdot \mathrm{ha}^{-1} \cdot \mathrm{year}^{-1}\right)$. $\mathrm{LH}(t)$ is dependent on the amount of trees to be harvested varying according to logging practices [25] (Sasaki et al. 2012). H(t) can be derived by:

$$
\begin{gathered}
\mathrm{H}(t)=\frac{f_{M} f_{H}}{1-r} \times \frac{\mathrm{CS}_{\text {above }}(t)}{\mathrm{CC} \times \mathrm{BEF}} \\
\mathrm{LM}(t)=\alpha \times \mathrm{H}(t)
\end{gathered}
$$

Deciding the initial values for carbon stocks i.e. $\mathrm{CS}_{\text {above }}(0)$ affects the results of carbon stocks, emissions or removals in Southeast Asia. Based on various sources (Table 4), average aboveground carbon stocks in forests in Southeast Asia are 151.1 MgC·ha ${ }^{-1}$ (129.6 - 172.6 for lower and upper bounce of 95\% confidence interval, respectively). Aye et al. [26] estimated that about $15.9 \%, 14.2 \%$, and $24.3 \%$ of aboveground carbon stocks in Myanmar's deciduous forests are in belowground, litters, and deadwood, respectively. We use these ratios for our study (Table 4).

Availability of mature trees in the forests and allowable rate for harvesting of these mature trees affect timber production and logging in the tropics. The two fractions were taken from Sasaki et al. [25] and set to $f_{H}=0.3$ and $f_{M}=0.43$ for PdF. BEF is biomass expansion factor (BEF $=1.74$ taken from [37] Brown, 1997). As explained early, carbon stocks in PrF is assumed to be constant. Cutting cycle (CC) is 30 years based on Sasaki et al. [25].

To estimate $r$, a number of sources were reviewed. The Forests and the European Union Resource Network [38] released an illegal logging statement claiming about $50 \%$ of the tropical wood products imported to the European Union came from illegal source. The illegal proportion of total wood products was between $50 \%$ and 
Table 4. Available data on aboveground carbon stocks in Southeast Asia.

\begin{tabular}{|c|c|c|}
\hline Country & Aboveground carbon stocks $\left(\mathrm{MgC} \cdot \mathrm{ha}^{-1}\right)$ & Reference \\
\hline Cambodia & 116.6 & [27] \\
\hline Indonesia & 243.0 & [28] \\
\hline Indonesia (Berau district) & 199.3 & [29] \\
\hline Malaysia & 138.0 & [30] \\
\hline Malaysia & 166.0 & [31] \\
\hline Malaysia & 164.0 & [31] \\
\hline Malaysia (Tangkulap) & 126.0 & {$[32]$} \\
\hline Malaysia (Deramakot) & 178.0 & [32] \\
\hline Malaysia (Pasoh) & 137.0 & [33] \\
\hline Malaysia (Pasoh) & 155.0 & [33] \\
\hline Myanmar & 116.6 & {$[26]$} \\
\hline Philippines & 193.0 & [34] \\
\hline Thailand & 71.6 & [35] \\
\hline Vietnam & 111.5 & {$[36]$} \\
\hline Average $\left(\mathrm{CS}_{\text {above }}\right)$ & 151.1 & $\begin{array}{l}129.6 \text { - } 172.6 \text { is for lower and upper bounce of } \\
95 \% \text { Confidence Interval, respectively }\end{array}$ \\
\hline Below $\left(\mathrm{CS}_{\text {below }}\right)$ & 24.0 & [26] \\
\hline Litters $\left(\mathrm{CS}_{\text {litters }}\right)$ & 21.5 & {$[26]$} \\
\hline Deadwood $\left(\mathrm{CS}_{\text {dead }}\right)$ & 36.7 & [26] \\
\hline Soil & (Not included) & \\
\hline Total (CS) & 233.3 & \\
\hline
\end{tabular}

80\% depending on political situation and locations on the country in the tropics [38]. Illegal logging in Cambodia was reported at $67 \%$ in 1997 [39]. While illegal logging is not constant over time, depending on political and economic situation in the countries in concern, here we assume that $50 \% \quad(r=0.5)$ of logging in PdF is illegal for 1990 through 2050 i.e. for the whole period of hypothetical REDD+ implementation. Revision of the parameter $r$ is highly recommended once data become available. Parameter values and variables for Equations (5)-(7) are given in Table 5.

MAI is an important indicator in forest management. Based on various studies in Southeast Asia [40]-[43] [27], a previous study by Kim Phat et al. [19] assumed a rate of $1 \mathrm{~m}^{3} \cdot \mathrm{ha}^{-1} \cdot \mathrm{yr}^{-1}$ for the MAI of tropical natural forests of Southeast Asia between 2000 and 2050. Based on evidence of long-term plots from 1975 to 1996, a biomass increase of $0.71 \pm 0.34 \mathrm{MgC} \cdot \mathrm{ha}^{-1} \cdot \mathrm{yr}^{-1}$ was observed for Amazonian forests [44]. The average volume increment for commercial timber in logged forests in Tapajós National Forest (Amazonia) has been estimated at $0.33 \mathrm{~m}^{3} \cdot \mathrm{ha}^{-1} \cdot \mathrm{yr}^{-1}$ or about $0.09 \mathrm{MgC} \cdot \mathrm{ha}^{-1} \cdot \mathrm{yr}^{-1}[45]$. Based on 12 - 17 years of measurements from experimental plots in national forests at Jarí and Tapajós, Amazonia, Alder and Silva [46] have estimated a MAI of 0.4 - 3.1 $\mathrm{m}^{3} \cdot \mathrm{ha}^{-1} \cdot \mathrm{yr}^{-1}$ or about $0.11-0.88 \mathrm{MgC} \cdot \mathrm{ha}^{-1} \cdot \mathrm{yr}^{-1}$. According to recent study of Wadsworth and Zweede [47] who focused their research on 24 crop trees in eastern Amazonia, logged forests were found to have a MAI of at least 0.56 to $0.67 \mathrm{~m}^{3} \cdot \mathrm{ha}^{-1} \cdot \mathrm{yr}^{-1}$. For this study, MAI is assumed to be $0.76 \mathrm{MgC} \cdot \mathrm{ha}^{-1} \cdot \mathrm{yr}^{-1}$.

Tree damages due to logging in relation to commercial stands were reported to be $60 \%$ for Sabah (Malaysia) by Tay et al. [48], 56\% for Sarawak (Malaysia) by FAO [49], and 48.4\% in East Kalimantan by Sist and Saridan [50]. Approximately $44 \%$ of the $60 \%$ reported by Tay et al. [48] were destroyed during the harvesting over a 60 -year cutting cycle or about $0.7 \% \mathrm{yr}^{-1}$. According to Sist et al. [50], logging caused $24.7 \%$ in dead commercial trees and $25.4 \%$ additional trees that were injured but not dead, in addition to canopy openings and damages to the soil. Pinard and Putz [31] found that $18 \%$ of all injured trees with DBH greater than $5 \mathrm{~cm}$ died after 12 months of harvesting. Iskandar et al. [51] reported that every one $\mathrm{m}^{3}$ of wood harvested led to the loss of 0.7 - 
Table 5. Initial values and parameters used for production forest (Equations (5)-(7)).

\begin{tabular}{|c|c|c|}
\hline Description & Conventional Logging (CVL) & Reduced Impact Logging (RIL) \\
\hline Initial carbon stocks $\mathrm{CS}_{\text {above }}(0)$ & 151.1 & 151.1 \\
\hline$f_{M}$ (Fraction of mature trees) & 0.43 & 0.43 \\
\hline$f_{H}$ (Logging rate) & 0.3 & 0.3 \\
\hline$r$ (Illegal logging rate) & 0.5 & 0.5 \\
\hline CC (Cutting cycle in year) & 30 & 30 \\
\hline MAI (Mean Annual Increment) & 0.76 & 0.76 \\
\hline BEF (Biomass Expansion Factor) & 1.74 & 1.74 \\
\hline$\alpha$ & 0.4 & 0.14 \\
\hline
\end{tabular}

$1.3 \mathrm{~m}^{3}$ due to logging damages. Recent study by Kimsun [52] suggested that logging damages under the RIL was $14 \%$ of the harvested wood. For this study, $\alpha$ is 0.40 ( $40 \%$ of harvested wood) is for damages under CVL and 0.14 is for damages under the RIL. More discussion on this variable will be discussed later in the paper.

Forest Plantations. Although tropical natural forests have been cleared, part of the deforested land has been gradually replaced forest plantation [20]. According to FAO [53], major tree species being planted in the tropics are eucalypts (23\%), pines (10.5\%), Acacia (7.7\%), and the rest comprises a mixture of fast-growing and native species. Based on various studies as seen in Table 6, average carbon stocks in forest plantations is 91.6 $\mathrm{MgC} \cdot \mathrm{ha}^{-1}$. Carbon stocks in forest plantation are therefore assumed to be constant using the average of carbon elsewhere in Southeast Asia of $92 \mathrm{MgC} \cdot \mathrm{ha}^{-1}$. We use $92.0 \mathrm{MgC}$ as carbon stocks in forest plantations in our study. Major forest plantations were well established before the beginning of the modeling timeframe. Carbon stocks in $\mathrm{FPl}, \mathrm{CS}_{\mathrm{FPl}}(t)$ are therefore

$$
\mathrm{CS}_{\mathrm{FPl}}(t)=\mathrm{CS}(0)=92
$$

\subsection{Carbon Stocks in Natural Forests and Forest Plantation}

The carbon stocks in natural forest in any given year is estimated by

$$
\mathrm{NF}_{\text {TOTAL }}(t)=\text { CS_PdF }(t) \times \operatorname{PdF}(t)+\mathrm{CS} \_\operatorname{PrF}(t) \times \operatorname{PrF}(t)
$$

where $\mathrm{NF}_{\text {TOTAL }}(t)$ is the carbon stock in natural forests at time $t$ (in TgC), CS_PdF $(t)$ and CS_PrF $(t)$ are the sums of all carbon pools (except soil carbon) per hectare in production and protected forests, respectively.

Clear-cut and re-plant are assumed to take place after a cutting rotation period of 10 years. Total carbon stocks in FPl after annual harvest is estimated by

$$
\mathrm{FPl}_{\text {TOTAL }}(t)=\mathrm{CS}_{\mathrm{FPl}}(t) \times\left[\operatorname{FPl}(t)-\frac{\mathrm{FPl}(t)}{10}\right]
$$

$\mathrm{FPl}_{\text {TотаL }}(t)$ is the total carbon stocks in forest plantations at time $t$ (in TgC).

The total carbon stocks in natural forests and forest plantations in Southeast Asia are therefore

$$
\mathrm{CS}_{\text {TOTAL }}(t)=\mathrm{NF}_{\text {TOTAL }}(t)+\mathrm{FPl}_{\text {TOTAL }}(t)
$$

\subsection{Carbon Emissions from Deforestation and Forest Degradation}

Establishment of baseline emissions or reference emission level is important for any developing country planning to receive financial support from developed countries under the REDD+ scheme. Total emissions from deforestation and forest degradation can be estimated by. 
Table 6. Carbon stocks in forest plantations by species in the tropics.

\begin{tabular}{|c|c|c|}
\hline Carbonstocks $\left(\mathrm{MgC} \cdot \mathrm{ha}^{-1}\right)$ & Remarks & References \\
\hline \multicolumn{3}{|c|}{ Pinuscaribaea } \\
\hline 130.2 & Various locations across Sri Landka & {$[54]$} \\
\hline $80.6(\mathrm{AG})$ & 15-year-old stand in Nigeria & {$[55]$} \\
\hline $103.5(\mathrm{AG})$ & 10-year-old stand in Nigeria & {$[56]$} \\
\hline 99.3 (AG) & Mid-country Wet Zone (WM3b) & {$[57]$} \\
\hline $76.2(\mathrm{AG})$ & Mid-country Intermediate Zone (IM1b) & {$[58]$} \\
\hline \multicolumn{3}{|c|}{ Eucalyptus grandis } \\
\hline 132.7 & Various locations across Sri Landka & {$[54]$} \\
\hline $197.0(\mathrm{AG})$ & 27-year-old stand in New South Wales, Australia & {$[58]$} \\
\hline $137.0(\mathrm{AG})$ & 12-year-old stand in New South Wales, Australia & [59] \\
\hline 234.5 & 19-year-old stand in Hatton, Sri Lanka & {$[60]$} \\
\hline $53.5-70.5(\mathrm{AG})$ & 5.5-year-old stand in Brazil & [61] \\
\hline \multicolumn{3}{|c|}{ Eucalyptus camaldulensis } \\
\hline 26.2 & Various locations across Sri Landka & {$[54]$} \\
\hline $13.5-17.5$ & 3.5-year-old stand in Southern Brazil & {$[62]$} \\
\hline 22.6 & 3-year-old stand in Southern India & {$[63]$} \\
\hline \multicolumn{3}{|c|}{ Tectona grandis } \\
\hline 42.7 & Various locations across Sri Landka & {$[54]$} \\
\hline $70.6(\mathrm{AG})$ & 15-year-old stand in Nigeria & {$[64]$} \\
\hline 120.0 & 20-year-old stand in Panama & {$[65]$} \\
\hline $142.0(\mathrm{AG})$ & 47-year-old stand in Costa Rica & {$[66]$} \\
\hline $113.0-191.0$ & Mature stand in South-Western Nigeria & {$[67]$} \\
\hline $70.6(\mathrm{AG})$ & 14-year-old stand in Nigeria & {$[64]$} \\
\hline $34.2(\mathrm{AG})$ & Philippines & {$[68]$} \\
\hline \multicolumn{3}{|c|}{ Swietenia macrophylla } \\
\hline 97.6 & Various locations across Sri Landka & {$[54]$} \\
\hline $130.5(\mathrm{AG})$ & 16-year-old stand in the Philippines & [69] \\
\hline 133.8 & Mature stands in the Philippines & {$[70]$} \\
\hline $61.9(\mathrm{AG})$ & 59-year-old stand in Puerto Rico & {$[71]$} \\
\hline \multicolumn{3}{|c|}{ Acacia mangium } \\
\hline 110.7 & Various locations across Sri Landka & [54] \\
\hline $45.2(\mathrm{AG})$ & 4-year-old stand in Malaysia & {$[72]$} \\
\hline $88.1(\mathrm{AG})$ & Philippines & [73] \\
\hline $25.6(\mathrm{AG})$ & Philippines & {$[74][68]$} \\
\hline \multicolumn{3}{|c|}{ Acaciaauriculiformis } \\
\hline 87.1 & Various locations across Sri Landka & {$[54]$} \\
\hline $76.8(\mathrm{AG})$ & Philippines & [68] \\
\hline & Assumption for this study: $92.0 \mathrm{MgC} \cdot \mathrm{ha}^{-1}$ & \\
\hline
\end{tabular}

Source: De Costa et al. [54]. Note: AG refers to above-ground carbon stocks. 


$$
\mathrm{E}_{\text {TOTAL }}(t n)=\mathrm{E}_{\text {DEFORESTATION }}(t n)+\mathrm{E}_{\text {DEGRADATION }}(t)
$$

Or

$$
\mathrm{E}_{\text {DEGRADATIon }}(t)=\mathrm{E}_{\text {Total }}(t n)-\mathrm{E}_{\text {Deforestation }}(t n)
$$

where $\mathrm{E}_{\text {TOTAL }}(t n), \mathrm{E}_{\text {DEForestation }}(t n)$, and $\mathrm{E}_{\text {DEGRADATION }}(t n)$ are total emissions, emissions from deforestation, and emissions from forest degradation, respectively at time $t=n \cdot \mathrm{E}_{\mathrm{TOTAL}}(t n)$ and $\mathrm{E}_{\text {DEForestation }}(t n)$ are obtained by

$$
\begin{gathered}
\mathrm{E}_{\text {TOTAL }}(t n)=\left[\mathrm{PdF}(t n) \times \mathrm{CS}_{\mathrm{PdF}}(t n)-\mathrm{PdF}(t n-1) \times \mathrm{CS}_{\mathrm{PdF}}(t n-1)\right] \times \frac{44}{12} \\
\mathrm{E}_{\text {DEFoReSTATION }}(t n)=\left\{[\operatorname{PdF}(t n)-\operatorname{PdF}(t n-1)] \times \mathrm{CS}_{\text {PdF }}(t n)\right\} \times \frac{44}{12}
\end{gathered}
$$

where $\operatorname{PdF}(t n)$ is area of PdF at time $t=n$ in million ha (Equation (1)), $\mathrm{CS}_{\mathrm{PdF}}(t n)$ is carbon stocks of PdF in $\mathrm{MgC} \cdot \mathrm{ha}^{-1}, 44 / 12$ is molecular weight of carbon dioxide per carbon unit. Unit for $\mathrm{E}_{\text {тотаL }}(t n)$, $\mathrm{E}_{\text {Deforestation }}(t n)$, and $\mathrm{E}_{\text {Degradation }}(t n)$ is $\operatorname{TgCO}_{2}\left(1 \mathrm{Tg}=10^{12} \mathrm{~g}=1\right.$ million.tonnes $)$.

\subsection{Carbon Emission Reductions and Removals}

Carbon-based financial compensation under the REDD+ scheme of the UNFCCC is a performance-based mechanism requiring the known amount of carbon emission reductions or removals resulted from policy interventions and actions in the field. In this paper, emission reductions can be achieved through reducing deforestation and forest degradation, while carbon removals can be achieved through forest plantations. Emission reductions (EDef $\mathrm{EEDUCTION}_{\text {) }}$ can be obtained using equation developed by Ty et al. [75]:

$$
\operatorname{EDef}_{\text {REDUCTION }}(t n)=\mathrm{E}_{\text {DEFORESTATIoN }}(t n) \times \operatorname{RPI}(t)
$$

where $\operatorname{RPI}(t n)$ is relative project impact at time $t=n$. It is the effects of policy interventions and projections undertaken to reduce drivers of deforestation, which in turn results in reducing deforestation. For simplicity, $\operatorname{RPI}(t)$ is taken directly from Ty et al. [75].

To estimate reductions from reducing forest degradation, we need to understand emissions in the absence of project activities and emissions when project is implemented to reduce forest degradation. The former is forest management using conventional logging, and the latter refers to forest management using reduced impact logging as in our present study. We assume that Reduced Impact Logging (RIL) is adopted as part of the management system required to achieve "sustainable management of forests" component of the REDD+ elements. Unlike conventional logging (Table 5), RIL is a logging practice that uses well-defined logging planning, welltrained staff, directional felling, and strictly follows logging code of practices or logging regulation (see [25] [76] for reviews of RIL). As reviewed by Sasaki and Putz [77], RIL can significantly reduce logging damages to residual stands, reduce wood and logging wastes resulted from untrained loggers, and reduce environmental damages to sensitive social and environmental areas in the forests in question. The difference between CVL and RIL is the damage caused by logging (i.e. $\mathrm{H}(t)$ in Equation (6) and Equation (7); Table 5). As seen in Table 5, logging damage is $40 \%$ and $14 \%$ under CVL and RIL, respectively. Emission reductions can be estimated by

$$
\begin{aligned}
& \operatorname{EDeg}_{\text {REduction }}(t n)=\mathrm{E}_{\text {DEGRADATION }}(t n) \\
& -\left\{\left[\operatorname{PdF}(t n) \times \mathrm{CS}_{\mathrm{RIL}}(t n)-\operatorname{PdF}(t n-1) \times \mathrm{CS}_{\mathrm{RIL}}(t n-1)\right]-[\operatorname{PdF}(t n)-\operatorname{PdF}(t n-1)] \times \mathrm{CS}_{\mathrm{RIL}}(t n)\right\} \times \frac{44}{12} .
\end{aligned}
$$

Definition of forest plantation under the REDD+ scheme is not yet defined. Afforestation and reforestation defined in 2001 for clean development mechanism of the Kyoto protocol can not be applied on deforested lands after 31 December 1989. Since no new definition was adopted for forest plantations implemented on deforested land after 2015 (the modeling timeframe for forest management), we assume that all carbon credits (removals) as a result of planting could be eligible for financial support under the REDD+ scheme. Carbon removals can be obtained by: 


$$
\mathrm{R}_{\mathrm{FPl}}(t n)=\mathrm{CS}_{\mathrm{FPl}}(t) \times\left[\mathrm{FPl}_{\mathrm{TOTAL}}(t n)-\mathrm{FPl}_{\mathrm{TOTAL}}(t n-1)\right] \times \frac{44}{12}
$$

\section{Results and Discussions}

\subsection{Land Use Change}

Parameter values of $a+b$ and $a$ and initial values for production forest (PdF) and forest plantation (FP) were derived by performing a least-square fit and regression analysis. According to regression resultsusing available data in 1990, 2000, 2005, and 2010, $a+b, a$, initial values for PdF and FPl are -0.0146 (decreases 1.46\%), 0.00286 ( $0.29 \%$ is converted back to forest plantation), 160.2 million ha, and 6.8 million ha, respectively. Using these parameters and initial values, area of production forest declined to 66.6 (34.3 - 129.5) million ha in 2050 from 160.2 (141.8 - 180.9) million ha, representing a loss of 1.6 million ha or about $-0.97 \%$ per year (Figure 1 ). Between 1990 and 2000 and 2000 and 2010, annual loss of production forest was estimated at 2.2 and 1.9 million ha, respectively. Because area of protected forest $(\mathrm{PrF})$ was assumed to remain unchanged, its change rate is zero. If no action to reducing or completely stopping deforestation, area of production forest will continue to decline and will be smaller than area of protected forest starting from 2039 onward. Consequently, even protected forest will be subject to clearing and commercially unless alternative sources are available sooner rather than later. Using data by FAO [78] (2005), Kim Phat et al. [19] estimated the loss of natural forests in Southeast Asia at 2.3 million ha between 1990 and 2000. By comparing the two studies, deforestation has slowed down.

In contrast, area of forest plantations increases to 25.1 (19.8 - 33.2) million ha in 2050 from 6.8 million ha in 1990. Area of forest plantations increases about 0.31 million ha per year $(4.49 \%)$ over the modeling period (Figure 2). Forest plantations increased about 0.43 million ha (6.32\%) between 1990 and 2000, and 0.37 million ha (3.33\%) between 2000 and 2010.

Over the whole Southeast Asia, area of natural forests declines to 144.4 million ha in 2050 from 238.0 million ha in 1990 with annual deforestation rate or $0.66 \%$ or about 1.56 million ha (Table 7). More specifically, deforestation rates were $0.92 \%$ and $0.87 \%$ between 1990 and 2000 and 2000 and 2010. Loss of natural forests is being compensated by the increase of forest plantations. As shown in Table 7 below, total area of forests (natural and plantation) in Southeast Asia declines only about $0.51 \%$ or about 1.25 million ha between 1990 and 2050. Deforestation in Southeast Asia between 1990 and 2000 and 2000 and 2010 was 1.75 (0.71\%) and 1.51 (0.67\%) million ha per year (Table 7). Our findings of deforestation were in the ranges estimated by Kindermann et al. [8]

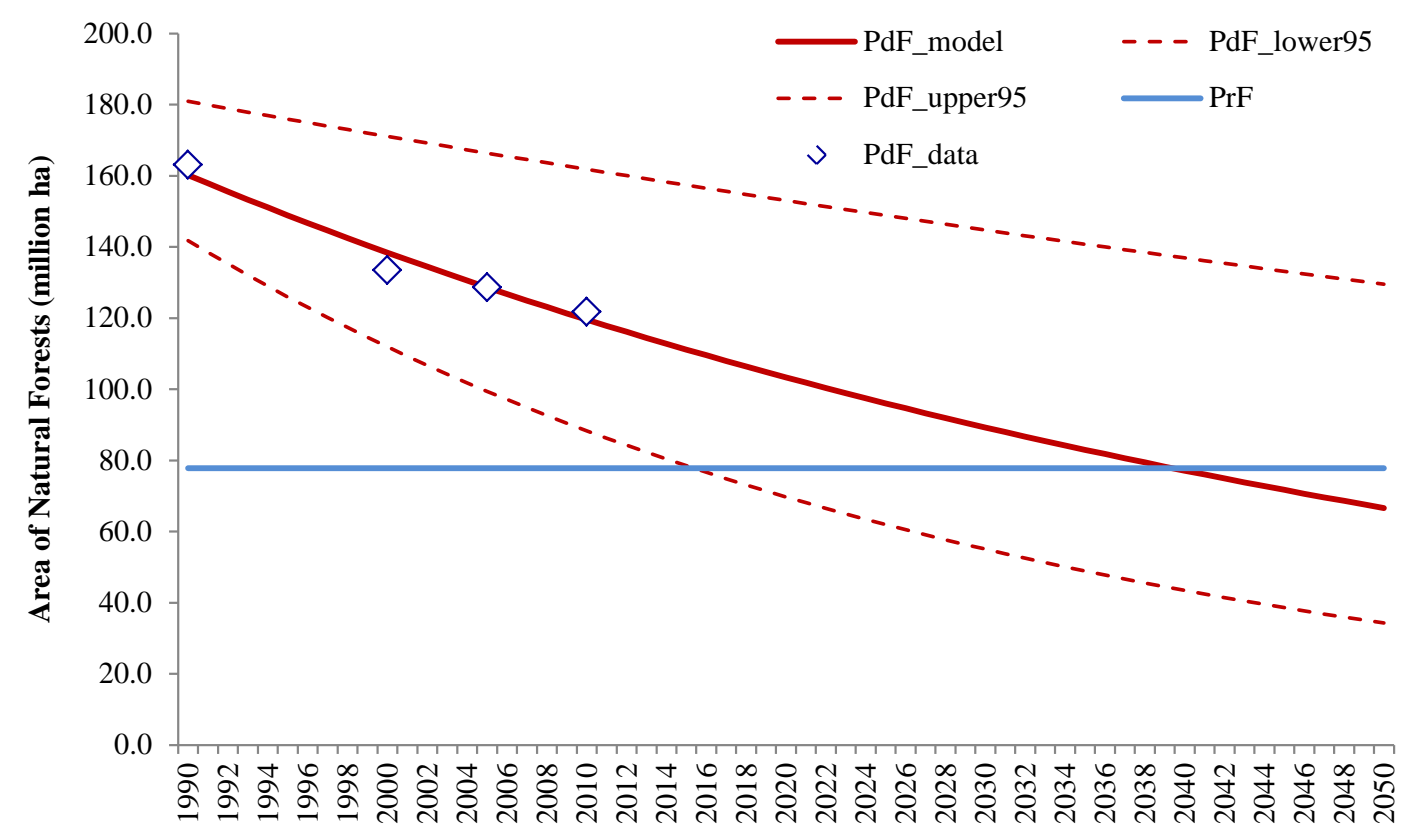

Figure 1. Area of natural forests in Southeast Asia (1990-2050). 


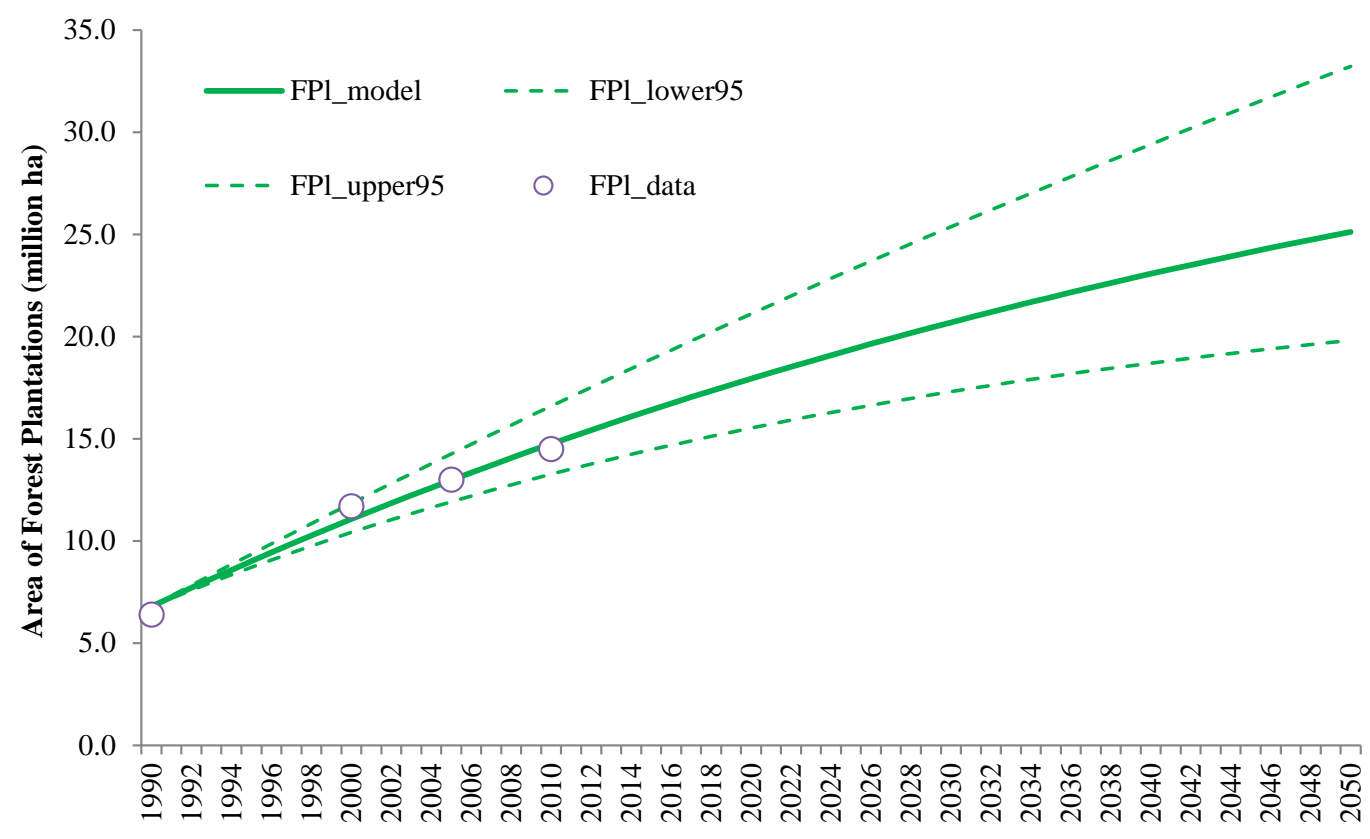

Figure 2. Area of forest plantations in Southeast Asia (1990-2050).

Table 7. Area of natural forests and forest plantations in Southeast Asia (modeling results).

\begin{tabular}{|c|c|c|c|c|c|}
\hline \multirow{2}{*}{ Year } & \multicolumn{3}{|c|}{ Natural Forests } & \multirow{2}{*}{ Forest Plantations (FPl) } & \multirow{2}{*}{ Total } \\
\hline & Production Forest (PdF) & Protected Forest (PrF) & Total & & \\
\hline 1990 & 160.2 & 77.8 & 238.0 & 6.8 & 244.8 \\
\hline 2000 & 138.4 & 77.8 & 216.2 & 11.1 & 227.3 \\
\hline 2010 & 119.6 & 77.8 & 197.4 & 14.8 & 212.1 \\
\hline 2050 & 66.6 & 77.8 & 144.4 & 25.1 & 169.6 \\
\hline \multicolumn{6}{|c|}{ Annual changes } \\
\hline $1990-2000$ & -2.18 & 0.0 & -2.18 & 0.43 & -1.75 \\
\hline Change rate & $-1.36 \%$ & $0.00 \%$ & $-0.92 \%$ & $6.32 \%$ & $-0.71 \%$ \\
\hline $2000-2010$ & -1.88 & 0.00 & -1.88 & 0.37 & -1.51 \\
\hline Change rate & $-1.36 \%$ & $0.00 \%$ & $-0.87 \%$ & $3.33 \%$ & $-0.67 \%$ \\
\hline $1990-2050$ & -1.56 & 0.00 & -1.56 & 0.31 & -1.25 \\
\hline Change rate & $-0.97 \%$ & $0.00 \%$ & $-0.66 \%$ & $4.49 \%$ & $-0.51 \%$ \\
\hline
\end{tabular}

Note: Area is in million ha, annual change is million ha per year, and change rate is \% proportional to area in the preceding year.

who estimated the loss of forests in Southeast Asia at $1.1-2.2$ million ha per year between 2005 and 2030 depending on chosen models. Miettinen et al. [79] estimated the deforestation rate in insular Southeast Asia at 1\% between 2000 and 2010, which well within our estimate of deforestation of natural forest.

\subsection{Carbon Emissions Due to Deforestation and Forest Degradation}

Carbon stocks in forests in Southeast Asia changed dramatically during the modeling period. No change in carbon stocks was observed in protected forest $(\mathrm{PrF})$ because of the study assumption. Deforestation and forest degradation led to decline of carbon stocks in production forest (PdF) from 37371.6 TgC (aboveground, belowground, litters, and deadwood) in 1990 to $13531.3 \mathrm{TgC}$ in 2050, representing an annual loss of $397.3 \mathrm{TgC}$. Annual losses between 1990-2000, 2000-2010, and 2015-2050 were 508.2, 439.1, and 354.3 TgC, respectively (Table 8). 
Table 8. Carbon stocks and changes in Southeast Asia.

\begin{tabular}{|c|c|c|c|c|}
\hline Year & Production Forest (PdF) & Protected Forest (PrF) & Forest Plantation (FPl) & Total \\
\hline \multicolumn{5}{|c|}{ Total carbon stocks in $\operatorname{TgC}(1 \mathrm{TgC}=1$ million tonnes $\mathrm{C})$} \\
\hline 1990 & 37371.6 & 18149.3 & 563.04 & 56083.9 \\
\hline 2000 & 32289.7 & 18149.3 & 916.446 & 51355.4 \\
\hline 2010 & 27898.8 & 18149.3 & 1221.79 & 47269.9 \\
\hline 2015 & 25932.6 & 18149.3 & 1358.53 & 45440.4 \\
\hline 2050 & 13531.3 & 18149.3 & 2080.69 & 33761.3 \\
\hline \multicolumn{5}{|c|}{ Annual changes in $\operatorname{TgC}$ year ${ }^{-1}$ and in $\operatorname{TgCO}_{2}$ year $^{-1}$ in ( ) } \\
\hline $1990-2000$ & $-508.2(-1865.1)$ & 0.0 & $35.3(129.7)$ & $-472.9(-1735.4)$ \\
\hline $2000-2010$ & $-439.1(-1611.5)$ & 0.0 & $30.5(112.1)$ & $-408.6(-1499.4)$ \\
\hline $1990-2050$ & $-397.3(-1458.2)$ & 0.0 & 25.3 (92.8) & $-372.0(-1365.4)$ \\
\hline $2015-2050$ & $-354.3(-1300.4)$ & 0.0 & 20.6 (75.7) & $-333.7(-1224.6)$ \\
\hline
\end{tabular}

These losses were compensated by the increase of carbon stocks in forest plantations. Over the same period,

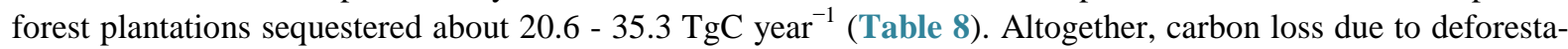
tion and forest degradation in Southeast Asia was 472.9 (1990-2000), 408.6 (2000-2010), and 372.0 TgC (1990-2050), respectively.

By assuming that REDD+ project will be implemented in 2015 and ended in 2050 (35 years), carbon emission during this period can be estimated. Deforestation of production forests emitted about $1400.0 \mathrm{TgCO}_{2}$ in 2015 , 1272.7 in 2020, 1054.3 in 2030, 876.2 in 2040, and $730.5 \mathrm{TgCO}_{2}$ in 2050 (Figure 3). On average between 2015 and 2050, deforestation emitted 1027.0 $\mathrm{TgC}_{\text {year }}{ }^{-1}$. In addition, degradation of production forest also emitted $275.0 \mathrm{TgCO}_{2}$ or about $26.8 \%$ of total emissions from deforestation. Emissions from deforestation and forest degradation were estimated to be $1302.0 \mathrm{TgCO}_{2}$ year $^{-1}$ between 2015 and 2050 (Figure 3). This figure is highly higher than that estimated by Kindermann et al. [8] who estimated emissions from deforestation in Southeast Asia at $1.1 \mathrm{TgCO}_{2}$ between 2005 and 2030. This is because their study did not include loss from forest degradation.

\subsection{Emission Reductions or Removals}

Over a 35-year period between 2015 and 2050, emissions from project implementation designed to reduce drivers of deforestation and forest degradation were estimated at $10468.8 \mathrm{TgCO}_{2}$ or about $290.8 \mathrm{TgCO}_{2}$ year $^{-1}$. Since total emissions in the absence of project activities (baseline emissions) were $36972.8 \mathrm{TgCO}_{2}$, reduced emissions were estimated at $26504.0 \mathrm{TgCO}_{2}$ per 35 years or $736.2 \mathrm{TgCO}_{2}$ per year (Table 9, Figure 4).

Over the same period, carbon emissions due to forest degradation in the absence of project activities (baseline emissions) i.e. using CVL were $9898.8 \mathrm{TgCO}_{2}$ and emissions from project implementation (i.e. using RIL) were $6970.5 \mathrm{TgCO}_{2}$, reduced emissions from forest degradation were therefore $2928.3 \mathrm{TgCO}_{2}$ or $81.3 \mathrm{TgCO}_{2}$ per year between 2015 and 2050 (Table 9, Figure 5).

In addition to reduced emissions from deforestation and forest degradation, forest plantations in Southeast Asia gained about 2745.3 $\mathrm{TgCO}_{2}$ or $76.3 \mathrm{TgCO}_{2}$ annually over the same period (Table 9). Altogether, carbon reductions and removals through implementing forestry project to reducing deforestation and forest degradation in Southeast Asia resulted in total reductions of $29432.3 \mathrm{TgCO}_{2}$ and removals of $2745.3 \mathrm{TgCO}_{2}$ for a 35-year project or about 817.6 and $76.3 \mathrm{TgCO}_{2}$ year $^{-1}$ (Table 9). With US $\$ 7.4$ per $\mathrm{MgCO}_{2}$ [80], total carbon revenues alone from reduced carbon emissions and increasing carbon stocks in Southeast Asia are \$237.8 billion for 35-year project or about 27\% of GDP in Indonesia in 2013. The annual carbon revenues are therefore $\$ 6.6$ billion or about 44\% of GDP in Cambodia in 2013. By implementing carbon projects designed to reducing deforestation and forest degradation, there are other benefits that could be achieved such as strengthening land tenure of local community, safeguarding of socio-economic values of local people, biodiversity, creating local employment, and improving local livelihood. 


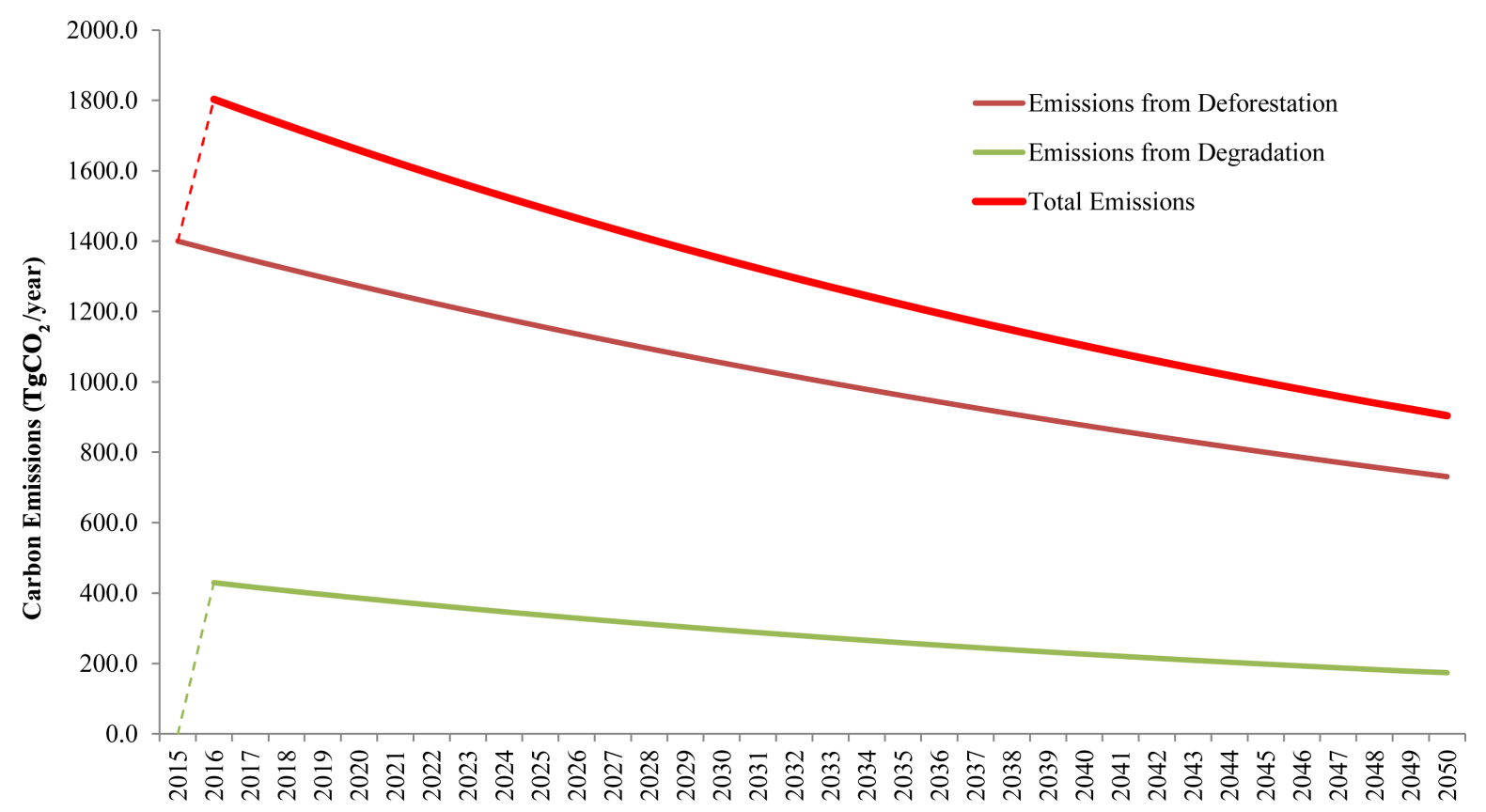

Figure 3. Annual carbon emissions from deforestation and forest degradation in Southeast Asia.

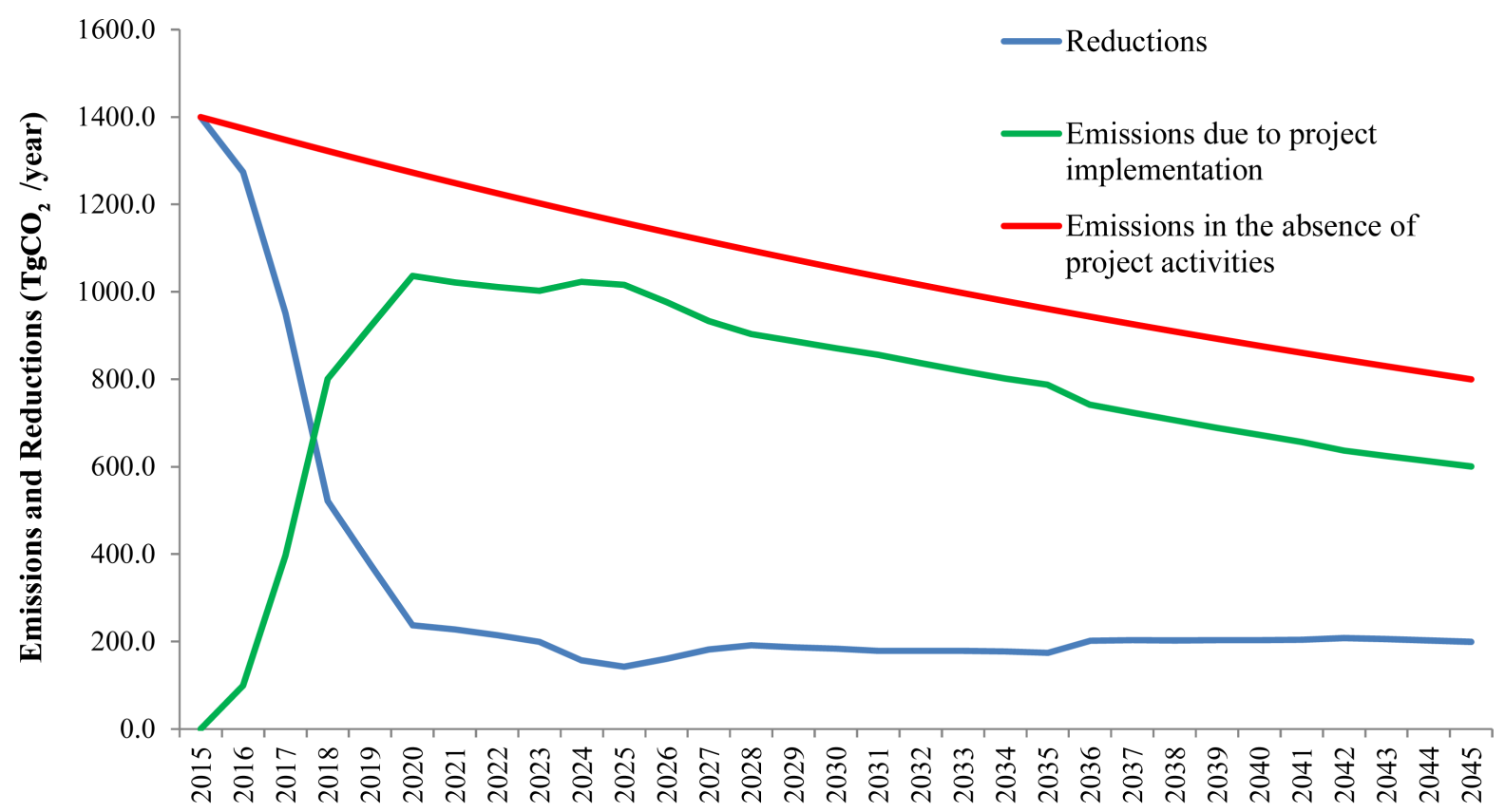

Figure 4. Emission reductions from reducing deforestation in production forest.

\subsection{Policy Implications for Protected Forest}

Forests in Southeast Asia are home to millions of flora and fauna. Some of flora and fauna have been threatened by the alarming loss of forests and repeated mismanagement of forests that has eventually led to rapid loss of important tree and wildlife species. In addition to such loss, deforestation and forest degradation continue to pose threats to livelihood of forest dependent communities as well as economic development in the region because of the adverse effects of climate change on agricultural production and water quality. Since the adoption of Bali Action Plan in 2007, there had been hope that REDD+ scheme would become a mitigation option for the post-Kyoto 


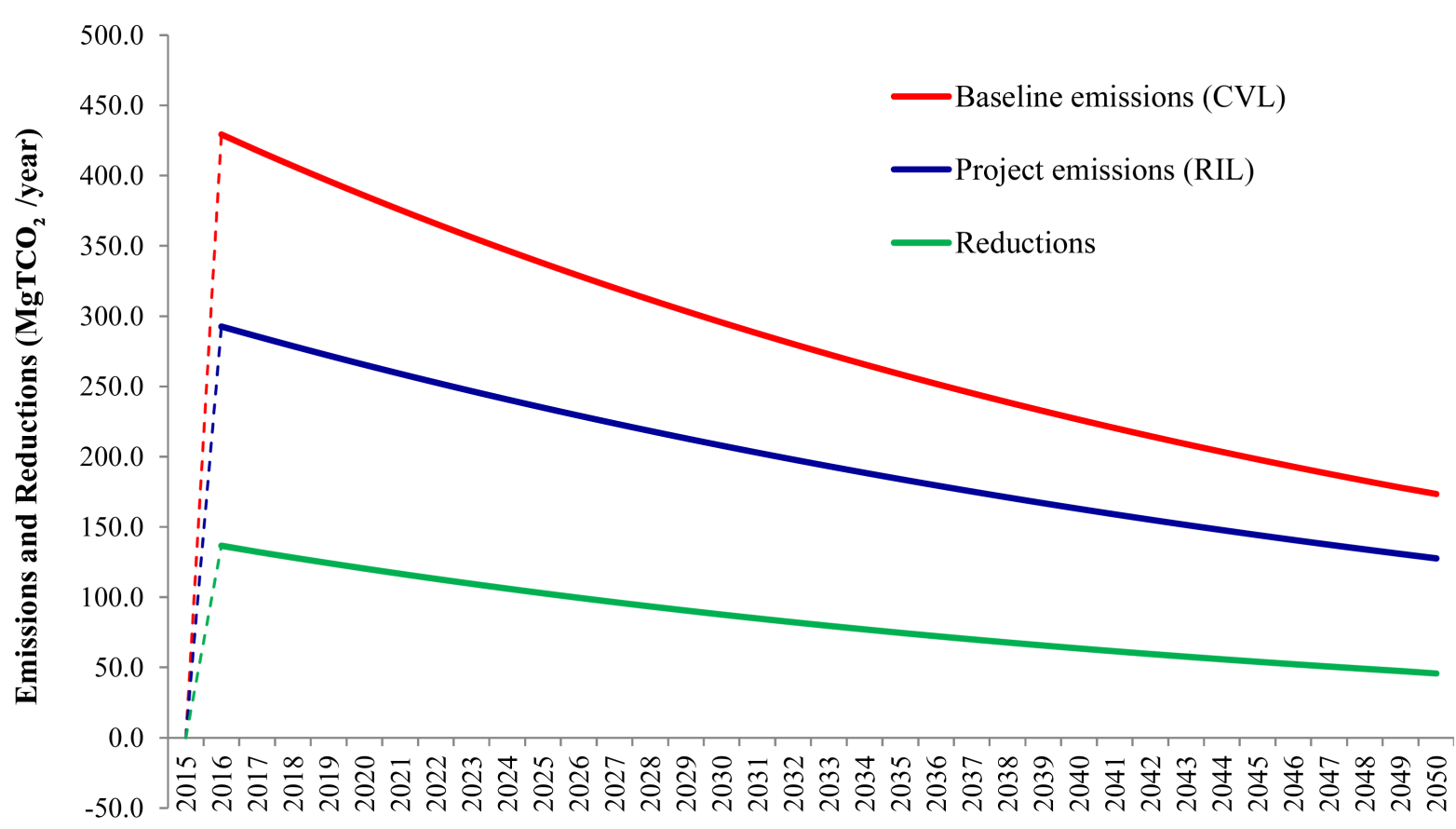

Figure 5. Emission reductions from reducing degradation in production forest.

Table 9. Baseline emissions, emission reductions, and removals in Southeast Asia.

\begin{tabular}{|c|c|c|c|c|}
\hline Description & Baseline emissions & Project emissions & Reductions & Removals \\
\hline \multicolumn{5}{|c|}{ Deforestation } \\
\hline 35 years & 36972.8 & 10468.8 & 26504.0 & \\
\hline Annual & 1027.0 & 290.8 & 736.2 & \\
\hline \multicolumn{5}{|c|}{ Forest degradation } \\
\hline 35 years & 9898.8 & 6970.5 & 2928.3 & \\
\hline Annual & 275.0 & 193.6 & 81.3 & \\
\hline \multicolumn{5}{|c|}{ Enhancement through plantation } \\
\hline 35 years & & & & 2745.3 \\
\hline Annual & & & & 76.3 \\
\hline \multicolumn{5}{|c|}{ Total } \\
\hline 35 years & 46871.6 & 17439.3 & 29432.3 & 2745.3 \\
\hline Annual & 1302.0 & 484.4 & 817.6 & 76.3 \\
\hline \multicolumn{5}{|c|}{ Revenues (billion dollars) } \\
\hline 35 years & 346.8 & 129.1 & 217.8 & 20.3 \\
\hline Annual & 9.6 & 3.6 & 6.0 & 0.6 \\
\hline
\end{tabular}

Note: Average carbon price from REDD+ project was \$7.40 in 2012 and \$4.20 in 2013 [80]. Carbon price was fluctuated in 2013 because global demand for carbon credits was significantly reduced due mainly to the lack of new climate agreement. Nevertheless as world leaders needed to decide on future climate regime by 2015 , it is expected that a new climate regime is anticipated and thus carbon price is likely to increase. For this study, $\$ 7.40$ per $\mathrm{MgCO}_{2}\left(t \mathrm{CO}_{2}\right)$ is used and therefore the derived number of carbon revenues should be used as indicative number. Future adjustment is needed when carbon price is known for some degree of uncertainty.

climate agreement, which was expected from 2013. Unfortunately, no agreement on future climate regime was reached and therefore REDD+ is still a voluntary scheme. Nevertheless, despite fluctuation of global carbon prices at the mandatory markets, carbon prices at voluntary markets did not change significantly compared to the 
former. Without losing hope, developing countries should continue to implement policies that will result in reducing deforestation and forest degradation. Well-thought policies designed to reduce drivers of deforestation and forest degradation should take into account the traditional uses of forest and non-forest products, transparency of benefit sharing that will ensure that any benefits from carbon projects will also reach local communities that are the main actors in either protecting the forests or destroying them. In addition to generating carbon revenues, world leaders have begun to discuss the payments for ecosystem services under the UN Convention on Biological Diversity.

Since constant value of forest area and carbon stocks were used, no change in area or carbon stocks was seen in protected forest during the modeling period. This is obviously true in the real world when forests are fully protected before the start of any carbon development projects, carbon-based incentives alone are not sufficient to encourage forest protection because no single carbon credit is gained. In the case of protected forests, payment for ecosystem services beyond carbon credits becomes urgently necessary. Otherwise, protected forests should be destroyed first in order to establish the baseline, against which emission reductions can be estimated and subsequently carbon-based revenues could be achieved. This scenarios is however worse because it encourages destruction of forests. As 2015 is approaching, world leaders need to consider not only carbon-based incentives but also alternative payment for ecosystem services provided by well-protected forests.

\section{Conclusions}

Reducing carbon emissions from deforestation and forest degradation, conservation of forests, sustainable management of forests, and enhancement of forest carbon stocks (REDD+) scheme of the UNFCCC was considered as a potential climate change mitigation options for future climate change regime. Under the REDD+ scheme, financial support to developing countries is expected to provide carbon emission reductions or removals can be achieved. We developed land use and carbon stocks models along with management scenarios to account for carbon balance, emission reductions or removals in Southeast Asia. Between 1990 and 2050, deforestation was 1.6 million ha or about $1.0 \%$ annually. Deforestation of natural forests was compensated by the increase of forest plantations whose area increased about 0.3 million ha or $4.5 \%$ annually over the same period. Carbon emissions due to deforestation and forest degradation were 1865.1, 1611.5, 1458.2, and $1300.4 \mathrm{TgCO}_{2}$ annually between 1990 and 2000, 2000 and 2010, 1990 and 2050, and 2015 and 2050, respectively. If financial support is available to implement REDD+ project, about $817.6 \mathrm{TgCO}_{2}$ year $^{-1}$ of reductions $(9.9 \%$ from reducing forest degradation) could be achieved for a 35-year project between 2015 and 2050. Over the same period, removals due to increase of forest plantations were estimated at $76.3 \mathrm{TgCO}_{2}$ annually depending on eligibility of accounted carbon. Altogether, carbon credits from reducing deforestation and forest degradations and forest plantations were estimated at $893.8 \mathrm{TgCO}_{2}$ or about US $\$ 6.6$ billion annually for 35 years of hypothetical carbon project if carbon is priced at $\$ 7.40$ per $\mathrm{MgCO}_{2}$.

Forest degradation resulted from the use of conventional logging not only poses threat to global carbon emissions, but also the biodiversity degradation because only highly valuable commercial trees are targeted. Including REDD+ as climate change mitigation option in the future climate regime has a great potential to reducing carbon emissions while safeguarding biodiversity and socio-economic values of local community in the tropics. Although forest plantations increasingly uptake atmospheric carbon, decision whether to harvest the forest at any given cutting rotation strongly affect carbon sequestration capacity. Decision for harvesting forest plantation should be based on further analysis on wood demands and wood availability from both natural forest and forest plantation. Since carbon sinks in forest plantations are credited under the first commitment period from 2008 and 2012, forest plantations are expected to continue to increase provided that future climate regime is agreed upon. Therefore, future study on carbon balance in the tropic forests should account for carbon uptakes in forest plantations separately. Nevertheless, forest plantations need better management and more attentions so as to avoid adverse impacts on local environment and biodiversity. From our study, it suggests that reducing deforestation and forest degradation has huge implications for climate change mitigation and sustainable development. Improved management of natural forests through the adoption of appropriate management system such as the use of reduced-impact logging would enhance carbon stocks in the forests and maintain or increase timber production for economic development and job generation. It is important that REDD+ be included as a climate change mitigation option and financial support for good forestry practices be made available continuously either through mandatory or voluntary markets or other form of payments. 
There are however limitations to this study. Prediction of future deforestation and forest degradation is difficult to validate because future development and political uncertainty in developing countries are unpredictable. Therefore, findings in this research should be used as indicative. In addition, deciding initial carbon stocks is important but it needs more data from the field in order to reduce uncertainty that would affect overall estimation of carbon emissions from deforestation and forest degradation. Initials should be revised when more data are available.

\section{Conflict of Interest}

The authors declare no conflict of interest.

\section{Acknowledgements}

This study was supported by a Grant-in-Aid for Scientific Research Category A (No. 24252002) from the Ministry of Education, Culture, Sports, Science and Technology of Japan.

\section{References}

[1] Achard, F., Eva, D.H., Mayaux, P., Stibig, H.J. and Belward, A. (2004) Improved Estimates of Net Carbon Emissions from Land Cover Change in the Tropics for the 1990s. Global Biogeochemical Cycles, 18, Article ID: GB2008. http://dx.doi.org/10.1029/2003GB002142

[2] Gullison, F.R., Frumhoff, C.P., Canadell, G.J., et al. (2007) Tropical Forests and Climate Policy. Science, 136, 985-986. http://dx.doi.org/10.1126/science.1136163

[3] Houghton, R.A. (2003) Revised Estimates of the Annual Net Flux of Carbon to the Atmosphere from Changes in Land Use and Land Management 1850-2000. Tellus 55B, 2, 378-390. http://dx.doi.org/10.1034/j.1600-0889.2003.01450.x

[4] Nepstad, D., Verssimo, A., Alencar, A., Nobre, C., et al. (1999) Large-Scale Impoverishment of Amazonian Forests by Logging and Fire. Nature, 398, 505-508. http://dx.doi.org/10.1038/19066

[5] Houghton, R.A., Skole, D.L., Nobre, C.A., et al. (2000) Annual Fluxes of Carbon from Deforestation and Regrowth in the Brazilian Amazon. Nature, 403, 301-304. http://dx.doi.org/10.1038/35002062

[6] UNFCCC (2008) Report of the Conference of the Parties on Its Thirteenth Session. Bali, 3-15 December 2007, 60 p.

[7] Miles, L. and Kapos, V. (2008) Reducing Greenhouse Gas Emissions from Deforestation and Forest Degradation: Global Land-Use Implications. Science, 320, 1454-1455. http://dx.doi.org/10.1126/science.1155358

[8] Kindermann, G., Obersteiner, M., Sohngen, B., et al. (2008) Global Cost Estimates of Reducing Carbon Emissions through Avoided Deforestation. Proceedings of the National Academy of Sciences of the USA, 105, 10302-10307. http://dx.doi.org/10.1073/pnas.0710616105

[9] Anger, N. and Sathaye, J. (2008) Reducing Deforestation and Trading Emissions: Economic Implications for the PostKyoto Carbon Market. Lawrence Berkeley National Laboratory, 39 p.

[10] Ebeling, J. and Yasue, M. (2008) Generating Carbon Finance through Avoided Deforestation and Its Potential to Create Climatic, Conservation and Human Development Benefits. Philosophical Transactions of the Royal Society B, 363, 1917-1924. http://dx.doi.org/10.1098/rstb.2007.0029

[11] De Fries, R., Achard, F., Brown, S., Herold, M., Murdiyarso, D., Schlamadinger, B. and de Souza Jr., C. (2007) Earth Observations for Estimating Greenhouse Gas Emissions from Deforestation in Developing Countries. Environmental Science and Policy, 10, 385-394. http://dx.doi.org/10.1016/j.envsci.2007.01.010

[12] Achard, F., Eva, H.D., Stibig, H.J., Mayaux, P., Gallego, J., Richards, T. and Malingreau, J.P. (2002) Determination of Deforestation Rates of the World's Humid Tropical Forests. Science, 297, 999-1002. http://dx.doi.org/10.1126/science.1070656

[13] Fearnside, P.M. and Laurance, W.F. (2003) Comment on “Determination of Deforestation Rates of the World's Humid Tropical Forests”. Science, 299, 1015. http://dx.doi.org/10.1126/science.1078714

[14] Eva, H.D., Achard, F., Stibig, H.J. and Mayaux, P. (2003) Response to Comment on Determination of Deforestation Rates of the World's Humid Tropical Forests. Science, 299, 1015. http://dx.doi.org/10.1126/science.1079819

[15] Houghton, R.A. (2003) Why Are Estimates of the Terrestrial Carbon Balance so Different? Global Change Biology, 9, 500-509. http://dx.doi.org/10.1046/j.1365-2486.2003.00620.x

[16] Intergovernmental Panel on Climate Change, IPCC (2000) Land Use, Land-Use Change and Forestry: A Special Report of the IPCC. Cambridge University Press, Cambridge, $377 \mathrm{p}$.

[17] Pan, Y., Birdsey, R.A., Fang, J., Houghton, R., Kauppi, P.E., Kurz, W.A., et al. (2011) A Large and Persistent Carbon 
Sink in the World's Forests. Science, 333, 988-993. http://dx.doi.org/10.1126/science.1201609

[18] FAO (2001) Global Forest Resource Assessments 2000 (Main Report). FAO Forestry Paper 140, Rome.

[19] Kim Phat, N., Knorr, W. and Kim, S. (2004) Appropriate Measures for Conservation of Terrestrial Carbon StocksAnalysis of Trends of Forest Management in Southeast Asia. Ecology Management, 191, 283-299. http://dx.doi.org/10.1016/j.foreco.2003.12.019

[20] Food and Agriculture Organization of the United Nations, FAO (2010) Global Forest Resources Assessment 2010. FAO Forestry Paper 163. FAO, Rome.

[21] IPCC (2006) 2006 IPCC Guidelines for National Greenhouse Gas Inventories. IPCC/OECD/IEA, Paris.

[22] Cerri, C.E.P., Coleman, K., Jenkinson, S.D., Bernoux, M., Victoria, R. and Cerri, C.C. (2003) Modeling Soil Carbon from Forest and Pasture Ecosystems of Amazon, Brazil. Soil Science Society of American Journal, 67, 1879-1887. http://dx.doi.org/10.2136/sssaj2003.1879

[23] Guo, L.B. and Gifford, R.M. (2002) Soil Carbon Stocks and Land Use Change: A Meta Analysis. Global Change Biology, 8, 345-360. http://dx.doi.org/10.1046/j.1354-1013.2002.00486.x

[24] Kim, S., Kim Phat, N., Koike, M. and Hayashi, H. (2006) Estimating Actual and Potential Government Revenues from Timber Harvesting in Cambodia. Forest Policy and Economy, 8, 625-635. http://dx.doi.org/10.1016/j.forpol.2004.12.001

[25] Sasaki, N., Kimsun, C. and Ty, S. (2012) Managing Production Forests for Timber Production and Carbon Emission Reductions under the REDD+ Scheme. Environmental Science \& Policy, 23, 35-44. http://dx.doi.org/10.1016/j.envsci.2012.06.009

[26] Aye, Y., Pampasit, S., Umponstira, C., Thanacharoenchanaphas, K. and Sasaki, N. (2014) Estimation of Carbon Emission Reductions by Managing Dry Mixed Deciduous Forest: Case Study in Popa Mountain Park. Low Carbon Economy, 5, 80-93. http://dx.doi.org/10.4236/lce.2014.52009

[27] Kim Phat, N., Ouk, S., Uozumi, Y. and Ueki, T. (2000) Stand Dynamics of Dipterocarp Trees in Cambodia's EverGreen Forest and Management Implications-A Case Study in Sandan District, Kamong Thom. Japanese Journal of Forest Planning, 6, 13-23.

[28] Griscom, B., Ganz, D., Virgilio, N., Price, F., Hayward, J., Cortez, R., et al. (2009) The Hidden Frontier of Forest Degradation: A Review of the Science, Policy and Practice of Reducing Degradation Emissions. The Nature Conservancy, Arlington.

[29] Sist, P. and Saridan, A. (1998) Description of the Primary Lowland Forest of Berau. In: Bertault, J.G. and Kadir, K., Eds., Silvicultural Research in a Lowland Mixed Dipterocarp Forest of East Kalimantan, The Contribution of STREK Project, CIRAD-FORDA-P.T. INHUTANII, 51-94.

[30] Berry, N.J., Phillips, O.L., Lewis, S.L., Hill, J.K., Edwards, D.P., Tawato, N.B., Ahmad, N., Magintan, D., Khen, C.V., Maryati, M., Ong, R.C. and Hamer, K.C. (2010) The High Value of Logged Tropical Forests: Lessons from Northern Borneo. Biodiversity and Conservation, 19, 985-997. http://dx.doi.org/10.1007/s10531-010-9779-z

[31] Pinard, A.M. and Putz, E.F. (1996) Retaining Forest Biomass by Reducing Logging Damage. Biotropica, 28, $278-295$. http://dx.doi.org/10.2307/2389193

[32] Imai, N., Samejima, H., Langner, A., Ong, R.C., Kita, S., Titin, J., et al. (2009) Co-Benefits of Sustainable Forest Management in Biodiversity Conservation and Carbon Sequestration. PLoS ONE, 4, e8267. http://dx.doi.org/10.1371/journal.pone.0008267

[33] Okuda, T., Suzuki, M., Numata, S., Yoshida, K., Nishimura, S., Adachi, N., Niiyama, K., Manokaran, N. and Hashim, M. (2004) Estimation of Aboveground Biomass in Logged and Primary Lowland Rainforests Using 3-D Photogrammetric Analysis. Forest Ecology and Management, 203, 63-75. http://dx.doi.org/10.1016/j.foreco.2004.07.056

[34] Lasco, R.D. and Pulhin, F.B. (2009) Carbon Budgets of Forest Ecosystems in the Philippines. Journal of Environmental Science and Management, 12, 1-13.

[35] Petsri, S. and Pumijumnong, N. (2007) Aboveground Carbon Content in Mixed Deciduous Forest and Teak Plantations. Environment and Natural Resources Journal, 5, 1-10.

[36] Van Con, T., Thang, N.T., Ha, D.T.T., Khiem, C.C., Quy, T.H., Lam, V.T., Van Do, T. and Sato, T. (2013) Relationship between Aboveground Biomass and Measures of Structure and Species Diversity in Tropical Forests of Vietnam. Forest Ecology and Management, 310, 213-218. http://dx.doi.org/10.1016/j.foreco.2013.08.034

[37] Brown, S. (1997) Estimating Biomass and Biomass Change of Tropical Forests: A Primer. FAO Forestry Paper 134, Rome.

[38] FERN, the Forests and the European Union Resource Network (2002) Illegal Logging, and the Global Trade in Illegally Sourced Timber; a Crime against Forests and Peoples. http://www.fern.org

[39] DAI (1998) Findings and Recommendations of the Log Monitoring and Logging Control Project. Report Submitted to 
the Royal Government of Cambodia, Department of Forestry and Wildlife, Phnom Penh.

[40] Food and Agriculture Organization of the United Nations (FAO) and United Nations Environment Program (UNEP) (1981) Tropical Forest Resources Assessment Project (in the Framework of GEMS). Forest Resources of Tropical Asia. Technical Report 3, FAO, Rome.

[41] International Tropical Timber Organization, ITTO (1994) The Economic Case for Natural Forest Management PCV (VI)/13. Volume II, Country Reports: Thailand 1-41, Malaysia 1-71 and Indonesia 1-27.

[42] Van, N.T. (1998) Forest Resources Utilization in Vietnam Transition from Natural Forests to Plantation. In: Yoshimoto, A. and Yukutake, K., Eds., Proceedings of International Symposium on Global Concerns for Forest Resource Utilization, Sustainable Use and Management, Japan Society of Forest Planning Press, Tokyo, 362-368.

[43] Kim Phat, N., Ouk, S., Uozumi, Y., et al. (2002) Management of Mixed Forest in Cambodia-A Case Study in Sandan District, Kamong Thom. Journal of the Faculty of Agriculture, 38, 45-54.

[44] Phillips, O.L., Malhi, Y., Higuchi, N., Laurance, W.F., Núñez, P.V., Vásquez, R.M., et al. (1998) Changes in the Carbon Balance of Tropical Forests: Evidence from Long-Term Plots. Science, 282, 439-442. http://dx.doi.org/10.1126/science.282.5388.439

[45] Van Gardingen, P.R., McLeish, M.J., Phillips, P.D., Fadilah, D., Tyrie, G. and Yasman, I. (2003) Financial and Ecological Analysis of Management Options for Logged-Over Dipterocarp Forests in Indonesian Borneo. Forest Ecology and Management, 183, 1-29. http://dx.doi.org/10.1016/S0378-1127(03)00097-5

[46] Alder, D. and Silva, J.N.M. (2000) An Empirical Cohort Model for Management of Terra Firme Forests in the Brazilian Amazon. Forest Ecology and Management, 130, 141-157. http://dx.doi.org/10.1016/S0378-1127(99)00196-6

[47] Wadsworth, F.H. and Zweede, J.C. (2006) Liberation: Acceptable Production of Tropical Forest Timber. Forest Ecology and Management, 233, 45-51. http://dx.doi.org/10.1016/j.foreco.2006.05.072

[48] Tay, J., Healey, J. and Price, C. (2002) Financial Assessment of Reduced Impact Logging Techniques in Sabah, Malaysia. In: Enters, T., Durst, B.T., Applegate, B.G., Kho, C.S.P. and Man, G., Eds., Applying Reduced Impact Logging to Advance Sustainable Forest Management, FAO, Bangkok, 125-140.

[49] FAO (2001) Financial and Economic Assessment of Timber Harvesting Operations in Sarawak, Malaysia. Forest Harvesting Case Studies 17, FAO, Rome.

[50] Sist, P., Sheil, D., Kartawinata, K. and Priyadi, H. (2003) Reduced-Impact Logging in Indonesian Borneo: Some Results Confirming the Need for New Silvicultural Prescriptions. Forest Ecology and Management, 179, 415-427. http://dx.doi.org/10.1016/S0378-1127(02)00533-9

[51] Iskandar, H., Snook, L.K., Toma, T., et al. (2006) Comparison of Damage Due to Logging under Different Forms of Resource Access in East Kalimantan, Indonesia. Forest Ecology and Management, 237, 83-93. http://dx.doi.org/10.1016/j.foreco.2006.09.079

[52] Kimsun, C., Sasaki, N. and Mizoue, N. (2011) Impacts of Reduced Impact Logging on Stand Structures in Mixed Forests in Three Northeastern Provinces in Cambodia. Proceedings of the 2nd International Conference on FORCOM Follow-Up and New Challenge for Coming Generations, Mie, 25-30 September 2011, 23 p.

[53] FAO (1995) Forest Resources Assessment 1990—Tropical Forest Plantation Resources. FAO Forestry Paper 128, Rome.

[54] De Costa, W.A.J.M. and Suranga, H.R. (2012) Estimation of Carbon Stocks in the Forest Plantations of Sri Lanka. Journal of National Science Foundation of Sri Lanka, 40, 9-41. http://dx.doi.org/10.4038/jnsfsr.v40i1.4166

[55] Kadeba, O. (1991) Above-Ground Biomass Production and Nutrient Accumulation in an Age Sequence of Pinus caribaea Stands. Forest Ecology and Management, 41, 237-248. http://dx.doi.org/10.1016/0378-1127(91)90106-6

[56] Egunjobi, J.K. and Bada, S.O. (1979) Biomass and Nutrient Distribution in Stands of Pinus caribea in the Dry Forestzone of Nigeria. Biotropica, 11, 130-135. http://dx.doi.org/10.2307/2387790

[57] Dharmaparakrama, S. (2006) Carbon Sequestration in Major Land Use Types in the Knuckles Forest and Surrounding Region, Sri Lanka. Ph.D. Thesis, University of Natural Resources and Applied Life Sciences, Vienna.

[58] Turner, J. and Lambert, M.J. (1983) Nutrient Cycling within a 27-Year-Old Eucalyptus grandis Plantation in New South Wales. Forest Ecology and Management, 6, 155-168. http://dx.doi.org/10.1016/0378-1127(83)90019-1

[59] Birk, E.M. and Turner, J. (1992) Response of Flooded gum (E. Grandis) to Intensive Cultural Treatments: Biomass and Nutrient Content of Eucalypt Plantations and Native Forests. Forest Ecology and Management, 47, 1-28. http://dx.doi.org/10.1016/0378-1127(92)90262-8

[60] Nissanka, S.P. and Ariyaratne, C.H.K. (2003) Estimation of Growth, Volume Accumulation and Carbon Sequestration of Eucalyptus grandis Plantations in up Country Region of Sri Lanka. Proceedings of the International Conference on Tropical Forests and Climate Change, Manila, 21-22 October 2003.

[61] Stape, J.L., Binkley, D. and Ryan, M.G. (2008) Production and Carbon Allocation in a Clonal Eucalyptus Plantation 
with Water and Nutrient Manipulations. Forest Ecology and Management, 255, 920-930. http://dx.doi.org/10.1016/j.foreco.2007.09.085

[62] Bernado, A.L., Reis, M.G.F., Reis, G.G., Harrison, R.B. and Firme, D.J. (1998) Effect of Spacing on Growth and Biomass Distribution in Eucalyptus camaldulensis, E. pellita and E. urophylla Plantations in Southeastern Brazil. Forest Ecology and Management, 104, 1-13. http://dx.doi.org/10.1016/S0378-1127(97)00199-0

[63] Hunter, I. (2001) Above Ground Biomass and Nutrient Uptake of Three Tree Species (Eucalyptus camaldulensis, Eucalyptus grandis and Dalbergia sissoo) as Affected by Irrigation and Fertiliser, at 3 Years of Age, in Southern India. Forest Ecology and Management, 144, 189-200. http://dx.doi.org/10.1016/S0378-1127(00)00373-X

[64] Mbaekwe, E.I. and Mackenzie, J.A. (2008) The Use of a Best-Fit Allometric Model to Estimate above Ground Biomass Accumulation and Distribution in an Age Series of Teak (Tectona grandis L.f.) Plantations at Gambari Forest Reserve, Oyo State, Nigeria. Tropical Ecology, 49, 259-270.

[65] Kraenzel, M., Castillo, A., Moore, T. and Potvin, C. (2003) Carbon Storage of Harvest-Age Teak (Tectona grandis) Plantations, Panama. Forest Ecology and Management, 173, 213-225. http://dx.doi.org/10.1016/S0378-1127(02)00002-6

[66] Pérez Cordero, L.D. and Kanninen, M. (2003) Above-Ground Biomass of Tectona grandis Plantations in Costa Rica. Journal of Tropical Forest Science, 15, 199-213.

[67] Ola-Adams, B.A. (1993) Effects of Spacing on Biomass Distribution and Nutrient Content of Tectona grandis Linn. f. (Teak) and Terminalia superba Engl. \& Diels. (Afara) in South-Western Nigeria. Forest Ecology and Management, 58, 299-319. http://dx.doi.org/10.1016/0378-1127(93)90152-D

[68] Lasco, R.D. and Pulhin, F.B. (2003) Philippine Forest Ecosystems and Climate Change: Carbon Stocks, Rate of Sequestration and the Kyoto Protocol. Annals of Tropical Research, 25, 37-51.

[69] Kawahara, T., Kanazawa, Y. and Sakurai S. (1981) Biomass and Net Production of Manmade Forests in the Philippines. Journal of the Japanese Forest Society, 63, 320-327.

[70] Racelis, M.E.L. (2000) Carbon Stock Assessment of Large Leaf Mahogany (Swietenia macrophylla King) and Dipterocarp Plantations in the Mt. Makiling Forest Reserve, Philippines. Master's Thesis, University of Philippines, Los Banos.

[71] Wadsworth, F., González, E., Colón, J.F. and Pérez, J. (2003) Fifty-Nine-Year Performance of Planted Big-Leaf Mahogany (Swietenia macrophylla King) in Puerto Rico. Ecological Studies, 159, 342-357. http://dx.doi.org/10.1007/0-387-21778-9 17

[72] Tsai, L.M. (1988) Studies on Acacia mangium in Kemasul Forest, Malaysia. I. Biomass and Productivity. Journal of Tropical Ecology, 4, 293-302. http://dx.doi.org/10.1017/S0266467400002856

[73] Lasco, R.D., Pulhin, F.B., Visco, R.G., Racelis, D.A., Guillermo, I.Q. and Sales, R.F. (2000) Carbon Stocks Assessment of Philippine Forest Ecosystems. Proceedings of Science-Policy Workshop on Terrestrial Carbon Assessment for Possible Carbon Trading, Bogor, 18-20 February 2000.

[74] Buante, C.R. (1997) Biomass Production of Acacia mangium Willd., Gmelina arborea Roxb., and Acacia auriculiformis A. Cunn. Ex Benth. as Fuel Wood Species in Leyte. Developments in Agroforestry Research. Book Series No. 160/1997, Philippine Council for Agriculture, Forestry and Natural Resources Research and Development, Los Baños, 224-246.

[75] Ty, S., Sasaki, N., Ahmad, A.H. and Zainal Ariffin, Z. (2011) REDD Development in Cambodia: Potential Carbon Emission Reductions in a REDD Project. FORMATH, 10, 1-23.

[76] Putz, F.E., Zuidema, P.A., Pinard, M.A., Boot, R.G.A., Sayer, J.A., Sheil, D., Sist, P. and Vanclay, J.K. (2008) Improved Tropical Forest Management for Carbon Retention. PLoS Biology, 6, e166. http://dx.doi.org/10.1371/journal.pbio.0060166

[77] Sasaki, N. and Putz, F.E. (2009) Critical Need for New Definitions of Forest and Forest Degradation in Global Climate Change Agreements. Conservation Letters, 2, 226-232. http://dx.doi.org/10.1111/j.1755-263X.2009.00067.x

[78] FAO (2005) Global Forest Resources Assessment 2005. Progress towards Sustainable Forest Management. FAO Forestry Paper 147, Rome, 350 p.

[79] Miettinen, J., Shi, C. and Liew, S.C. (2011) Deforestation Rates in Insular Southeast Asia between 2000 and 2010. Global Change Biology, 17, e2261-e2270.

[80] Peters-Stanley, M. and Gonzalez, G. (2014) Sharing the Stage State of the Voluntary Carbon Markets 2014. A Report by Forest Trends’ Ecosystem Marketplace: Executive Summary, Washington DC, 22 p. 
Scientific Research Publishing (SCIRP) is one of the largest Open Access journal publishers. It is currently publishing more than 200 open access, online, peer-reviewed journals covering a wide range of academic disciplines. SCIRP serves the worldwide academic communities and contributes to the progress and application of science with its publication.

Other selected journals from SCIRP are listed as below. Submit your manuscript to us via either submit@scirp.org or Online Submission Portal.
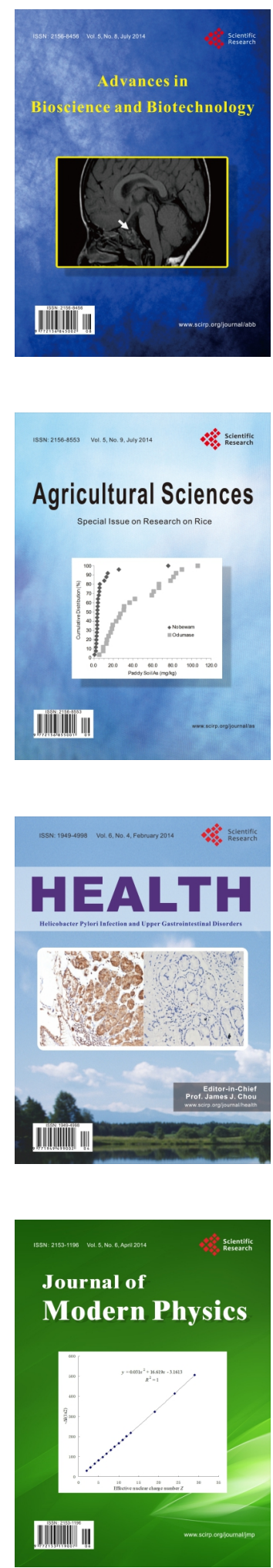
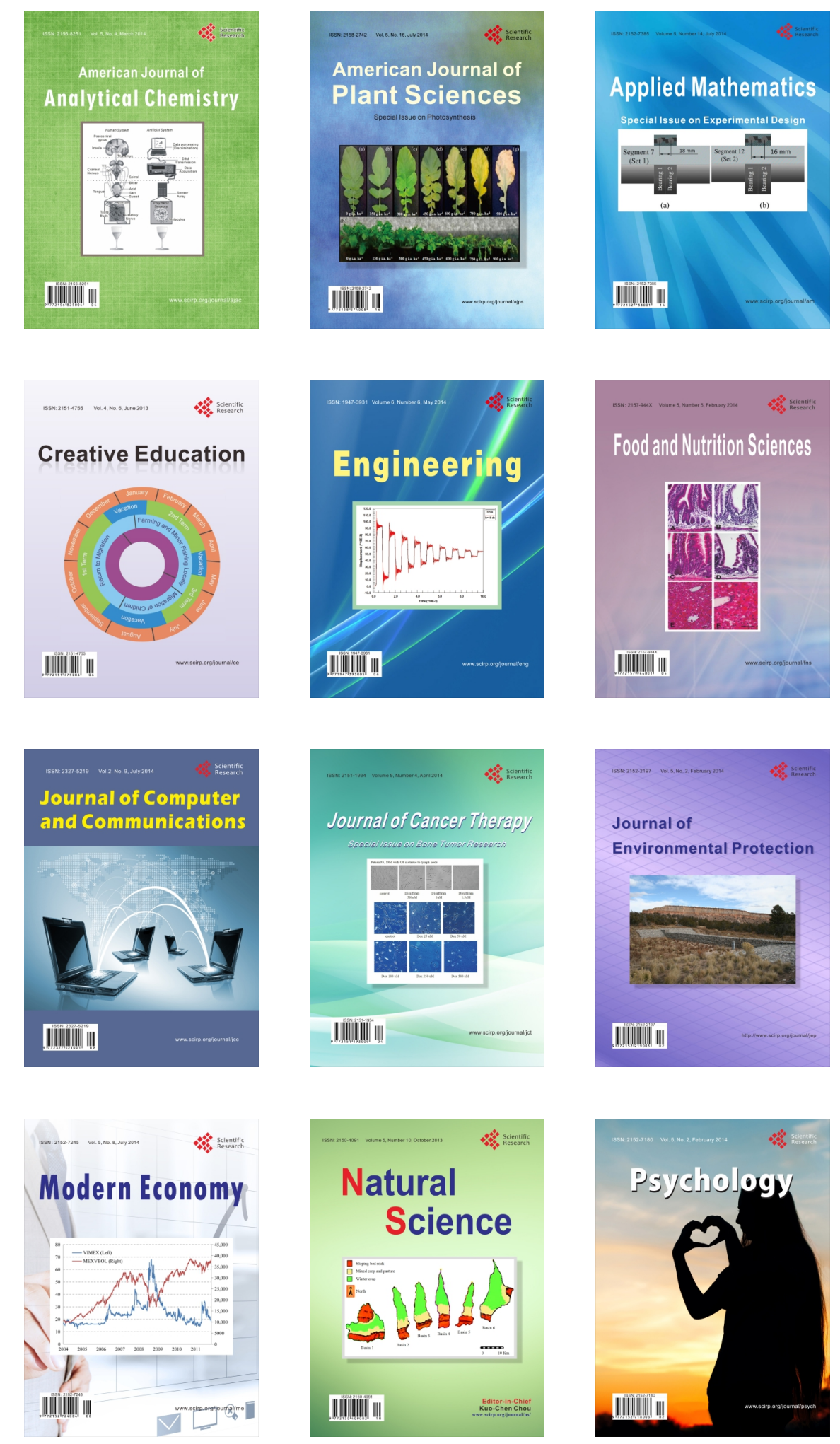